\title{
EVIDENCE OF GHARACTER TO PROVE CONDUGT: ILLUSION, ILLOGIC, AND INJUSTICE IN THE GOURTROOM
}

\section{H. RICHARD UVILLER $\dagger$}

The process of litigation is designed for the reconstruction of an event that occurred in the recent past. And for the most part, the rules by which a trial is conducted are supposed to enhance the accuracy of the synthetic fact. ${ }^{1}$ Of course, the success of this enterprise, while not unknowable, will always be shrouded in uncertainty. Those in a position to measure verity will forever disagree and the rest of us will never be sure whose report to credit. Yet the process continues, and lives by a faith in a collective intuition, which is the genius of a system of law-by-development such as ours.

Fortunately, our faith in the mechanism of adjudication is not unshakeable, and my purpose in this Article is gently to shake some cherished assumptions concerning a group of evidentiary rules allocating inferences from experience. A fuller description of my thesis must await the setting of its underpinnings.

\section{INTRODUCTION}

The means by which our legal facsimile of truth is recreated is the production of "evidence." In the United States, at least, ${ }^{2}$ elab-

† Professor of Law, Columbia University. B.A. 1951, Harvard University; LL.B. 1953, Yale University. My gratitude is expressed to my good friend and esteemed colleague, Professor Jon Waltz of Northwestern University School of Law, for his careful editorial review of the draft, his valuable suggestions, and his words of encouragement. I also acknowledge with thanks the assistance of Jonna Schuder, Columbia Law 1981, who did research for the footnotes to this Article.

1 Members of the Supreme Court have mentioned, from time to time, that a major objective of litigation is to obtain a close correspondence between proven fact and historical truth. Justice White, for one, is of this view. Writing for a bare majority in United States v. Havens, 446 U.S. 620 (1980), he permitted the use on cross-examination of a T-shirt previously suppressed as the product of an unlawful search and seizure. He relied in part on Walder v. United States, 347 U.S. 62 (1954), and consistent later cases, writing that, in those cases, "the Court stressed the importance of arriving at the truth in criminal trials." 446 U.S. at 626. The wealth of other recent cases that have followed this homily indicates that it is fast becoming a major theme of contemporary criminal jurisprudence. See, e.g., United States v. Hernandez, 646 F.2d 970, 974-78 (5th Cir.), cert. denied, 102 S. Ct. 638 (1981); United States v. Rada-Solano, 625 F.2d 577, 579 (5th Cir.), cert. denied, 449 U.S. 1021 (1980); United States v. Hinckley, 529 F. Supp. 520, 522 (D.D.C. 1982).

2 It comes as a surprise to American lawyers and law students to discover that a substantial number of highly developed legal systems-notably European-carry on litigation quite comfortably without any discernible "law of evidence." See 
orate rules have developed regarding what is evidence and what it proves. For all the criticism of their many faults, the rules of proof refuse to be blown away. Quite the contrary; federal codification, followed with varying alacrity and enthusiasm by some states, has added some support to many sagging beams of the common law rules of evidence. At the same time, codification has enhanced the visibility of numerous courtroom conventions, drawing interest and focusing dispute. So, call our rules an ornamented baroque partita on a two note theme ("probative" or "prejudicial"); call them an arcane mythology (e.g., the hearsay exceptions); call them an unintelligible pastiche of meaningless obstacles to realistic fact-gathering (e.g., the "best evidence rule" in a print-out world); call them a needless invitation to lawyer-scholasticism at its stultifying worst (e.g., the rule of privity of interest for adverse party admissions); or sum them up as a vestige of elitist distrust of jury intelligence. Hang whatever epithet on the rules you choose (most are richly deserved)-evidence remains the language American lawyers speak. And I suspect the reason is not merely force of communal habit or the need for a professional tongue, though both are important. Although its dogma sometimes receives only a nod of recognition in the courtroom, I believe evidence remains alive in American legal parlance and thought because the rules express some usable ideas about one of the main concerns of the lawyer: the establishment of a fact as true.

We are all in the proof business, one way or another. As we assemble our evidence, we usually adopt the footprint theory of how to show who passed by. According to this theory, the past is preserved in the present by altered surfaces of matter and mind. It is a good theory because it takes as its major premise an undoubted and common occurrence. Ordinary experience teaches

generally R. SchLesinger, Comparative Law (3d ed. 1970). Casually, at least, continental lawyers attribute their open proof mode to the absence of lay juries. It also may reflect a considerably more muted tradition of adversary contention compared to that which characterizes the domestic litigation process. See 9 J. Wigmore, Evionnce IN Truats at Common LAw \$2483 (Chadboum rev. 1981) [hereinafter cited as WrGMoRE]; Goodhart, A Changing Approach to the Law of Evidence, 51 VA. L. REv. 759 (1965); Kunert, Some Observations on the Origin and Structure of Evidence Rules Under the Common Law System and the Civil Law System of "Free Proof" in the German Code of Criminal Procedure, 16 Buffalo L. Rev. 122 (1966); Ploscowe, The Development of Present-Day Criminal Procedures in Europe and America, 48 Harv. L. Rev. 433 (1935). Although the Mother Common Law country employs evidentiary conventions resembling many of our own, see J. Magutre, J. Weinstein, J. Chadbourn \& J. Mansfield, Cases and Materuals on Evidence (6th ed. 1973) [hereinafter cited as Maguire], neither the British nor the Canadians have developed nearly so complex or so important a set of rules and law governing proof as we have. 
that events frequently do leave durable marks in the physical world and imprints on the minds of witnesses. Detect, inspect, collect, and resurrect these little clues, then, and the truth is proved. The apt image of the factual or evidentiary side of the law is Holmes (Sherlock, here, not O.W., Jr.) peering through his hand lens at the telltale scratch.

Of course, not every trace is fixed in form or unambiguous in significance. Evidence from human witnesses, for example, must be received with special caution because, as we all know, initial perception may have been incomplete or inaccurate, memory is sometimes fluid, and recitation may be consciously or unconsciously skewed. Even inanimate objects-in themselves, in their location, or in the marks they bear-may provide evidence consistent with more than one version of the happenings in which they were involved or affected. Yet the miracle of proof is that, by gathering and putting together enough evidentiary traces, ambiguities can be canceled, distortions can be revealed and discounted, and a fair similitude of the past event can be achieved. ${ }^{3}$

In sum, the predominant theory of evidence holds that nothing passes in this world without leaving a trace, and current phenomena, properly sorted and compiled, speak clearly of earlier events. It works for archeologists and paleontologists; it works for us. It is not, however, the thesis to which I wish to devote attention here.

Apart from evidence admitted for the trace of an event, the truth-seeker may consider certain facts for their value as predictors of behavior or events. The probity of this second category of evidence is based upon the common concurrence or predictable recurrence of certain events or behavioral patterns. To illustrate: the trace method of proving that a nail was struck by a hammer is to examine the head of the nail and there discover the trace of a hammer blow. Another way is to establish that a certain person, being a carpenter, has frequently hit nails with his hammer and, having had the opportunity and motive to do so, he probably struck the nail in question. Rather than looking back from the effect to its probable cause, predictive reasoning looks forward from an established event or trait to predict the likely repetition of its occurrence, or future conduct consistent with the observed character of the actor. Thus, the governing assumption is something like this: habits persist, events recur in familiar form, and the

${ }^{3}$ As with most miracles, belief requires a bit of faith. But old trial hands generally agree that, despite the weakness of any individual piece of proof, the trace evidence as a whole, wrung out by the customary trial process, usually presents a reliable picture of the event in issue. 
peculiarity of individuality continues to identify the actor in successive transactions. ${ }^{4}$

Predictive evidence is really no alien in the land of conventional modes of proof by traces and residues. In a logical sense, predictive evidence is the primal ancestor of the more familiar genus. Consider: why is the footprint relevant to the foot's passage? Having observed feet pressed into smooth wet sand, having observed muddy shoes walking on clean floors, having had a variety of experience with similar events involving the track of feet, we are prepared to say that, because a foot pressed to a surface will leave a characteristic imprint, therefore such a print was in all likelihood made by a foot. Thus, while we appear to be reasoning backward from the trace, we are actually applying experience with many half-forgotten similar events that have taught us to expect co-existing or sequential phenomena. It is, in short, the predictive lesson of experience that accords validity to judicial retrospective reasoning.

Outside of the courtroom, of course, we make judgments every day based on associative or predictive assumptions. Indeed, many of us spend more time than we should finely analyzing character in order to guess at the behavior of others. The comment, "I'm sure he did it; it's just the sort of thing he would do," is so common it passes without notice as a system of proof. So, too, we all think it sensible to lock the office door after the typewriter is stolen from the office next door. Because we all believe that people act predictably according to character, should not proof of character be admitted in court to demonstrate expected conduct? And if our pooled experience leads us to expect repetitions of characteristic conduct, why should we not treat a prior similar action as evidence of the behavior in question? Proof, in court at least, is supposed to be a matter for the application of ordinary intelligence, and any rule in derogation of common sense requires special justification.

The law, I shall argue, has been particularly squeamish about predictive evidence; the result has been uncertain, inconsistent, and ill-defined rules. The response of the common law is best sum-

4 My definition of "predictive" evidence covers two specific forms of proof which I do not intend to discuss in these pages: evidence of habit or routine, and evidence of prior similar happening. In my view, both share with character evidence the assumptions described in the text. The governing rules, however, are not altogether harmonious. Personal habit, inappropriately linked with institutional routine by Federal Rule of Evidence 406 , is welcomed as proof of particular conduct in conformity. Prior events similar to the one in issue are not treated explicitly by the federal rules, and the case law is fluid. The admissibility of the evidence appears to be controlled by general rules of relevancy. See McCormack's HandBOOK OF THE LAW OF EvDENCE $\$ \oint 196-200$ (E. Cleary 2d ed. 1972) [hereinafter cited as MCCormick]. 
marized as: "Yes and no. For some purposes, in some sorts of cases, under some conditions, perhaps." 5 The Federal Rules of Evidence do not handle the matter much better. ${ }^{6}$

\section{The Rules Governing the Methods of Proving Gharagter}

\section{A. In General}

In the simplified lexicon of evidence law, "character" may be understood to be a collection of "traits," each a self-contained packet of potential conduct consistent with previously observed reactions to events, people, or things. ${ }^{7}$ These behavioral fragments are organized according to our English vocabulary; the items of behavior composing each trait cluster about a common descriptive term such as "forgetful," "aggressive," or "honest." By our careless usage, many of these linguistic boxes have lost their integrity. A term thought to describe a discrete and persistent element of personality, such as "law-abiding" or "cautious," may arise from a wide range of behavioral events or attitudes, and affords only the crudest index for the prediction of a given act consistent with it. The semantic problem of precision and narrowness in the categorization of character traits may be an important feature in the reluctance of the law of evidence to appreciate the value of character evidence; as such it deserves further attention, which I shall attempt to lavish upon it further along.

Character or a character trait is normally proved by one of three available means: reputation, specific manifestation, and sometimes, opinion. ${ }^{8}$ Reputation evidence is adduced by asking a witness acquainted with the community view of the subject to report on the general regard. ${ }^{9}$ In the second mode, the witness is permitted to recount otherwise unconnected incidents in which the subject behaved in a manner exhibiting the characteristic in ques-

5 See, e.g., McConmax, supra note 4, $\$ 186$; Udall, Character Proof in the Law of Evidence-A Summary, 18 U. Cn. L. Rev. 283 (1949).

6 See, e.g., FED. R. Evm. 403-405.

$\tau$ Character is defined as " $[t]$ he aggregate of the moral qualities which belong to and distinguish an individual person; the general result of the [sic] one's distinguishing attributes." BLACK's LAw DrCTIONARY 211 (rev. 5th ed. 1979).

8 Fed. R. Evm. 405; 1 S. Greenteaf, A Treatise on the Law of Evidence $\$ \$ 14 c$, 461a-d (16th ed. 1899) [hereinafter cited as GreenLeaf]; McCormack, supra note 4, \$186; 3A WrGMORE, supra note 2, \$920 (Chadbourn rev. 1970).

9 See FED. R. EvD. 405 advisory committee note. When reputation testimony is offered, the reputation may be that in the general community in which the person resides or that among a group of associates. See United States v. Oliver, 492 F.2d 943 (8th Cir. 1974), appeal after remand, 525 F.2d 731 (8th Cir. 1975), cert. denied, 424 U.S. 973 (1976). 
tion. $^{10}$ By opinion evidence, we mean simply that a witness may recite his own opinion of the subject's character as to the relevant trait."

Although the probative value of evidence of specific acts exhibiting the trait in question is probably superior to proof by either of the other two modes, ${ }^{12}$ it is also thought to be most distracting and time consuming. ${ }^{13}$ Both the contemporary common law ${ }^{14}$ and the federal rules, ${ }^{15}$ therefore, bar proof of character in this manner, except for those cases in which character itself constitutes a substantive issue, or, for impeachment purposes, when the proof is by previous conviction. ${ }^{16}$ The rule against demonstration of character by prior conduct, however, does not preclude the cross-examination of a witness, who is giving evidence of character by reputation or opinion, concerning specific behavior of the subject tending to contradict the witness's expressed belief concern-

10 Under FED. R. EVD. 405(a), specific instances of relevant conduct may only be brought out on cross-examination, see United States v. Reese, 568 F.2d 1246 (6th Cir. 1977), unless character is "an essential element of a charge, claim, or defense." FED. R. Evm. 405(b). A reputation or opinion witness may only be asked either "if he knows" or "has heard" of the specific acts. See FED. R. Evw. 405 advisory committee note; McCorMrck, supra note $4, \$ 191$, at 457 n.74. Relevant specific acts are not limited to instances resulting in conviction. United States v. Edwards, 549 F.2d 362 (5th Cir. 1977); United States v. Lewis, 482 F.2d 632 (D.C. Cir. 1973).

11 The witness must first establish familiarity with the person before testifying as to an opinion. See Virgin Islands v. Petersen, 553 F.2d 324 (3d Cir. 1977); Ladd, Credibility Tests-Current Trends, 89 U. PA. L. Rev. 166, 173-74 (1940).

12 As I shall argue below, see infra notes 113-14 and accompanying text, proof of observed conduct that is idiosyncratic or habitual provides the strongest reason to expect its recurrence as a demonstrated behavioral characteristic of the subject. If sufficiently similar in nature of circumstances to the conduct in issue, the prior behavior tends to establish the successive act. By contrast, both reputation and opinion concerning character are often diffuse and necessarily highly interpretive formulations of unreliable data from unknown sources.

13 See FED. R. Evin. 405 advisory committee note. See generally Kuhns, The Propensity to Misunderstand the Character of Specific Acts Evidence, 66 Iowa L. REv. 777 (1981).

14 Against the criminal defendant, particular acts or misconduct were inadmissible to show bad character. I GREENLEAF, supra note $8, \S 461$ (b); 1 WIGMone, supra note 2, §193 (3d ed. 1940).

Against other witnesses, until the 1700 's, the common law permitted a witness to testify about the specific acts of another witness. Comment on specific acts flowed naturally from the witness's opinion testimony. During the early 1700's, both English and American courts began excluding specific conduct evidence because it was confusing, time-consuming, and unfairly surprising. Id. $\$ 979$ (Chadbourn rev. 1970).

15 FED. R. Evid. 405 permits the use of specific conduct evidence on crossexamination and when character is an essential element of a charge, claim, or defense. FED. R. EVID. 608 limits the use of specific conduct evidence other than conviction of a crime to the cross-examination of a witness concerning truthfulness and, even then, gives the court discretion to admit or exclude such evidence. See supra note 10.

16 See infra notes 59-109 and accompanying text; FED. R. Evro. 608-609. 
ing the trait in question. ${ }^{17}$ Mercifully, these oddities of trial mechanics need not concern us greatly. It is enough to know that all three modes of proof are acceptable under some circumstances: proof by reputation is the most generally acceptable (and probably the least valuable), proof by opinion is making a strong comeback (thanks no doubt to Wigmore's view of it), ${ }^{18}$ and conduct (the most probative) is the most sharply limited.

Be not misled, however, by the law's provision for the several means by which character may be proved. The prevailing response of the law and legal scholars to such evidence has been decidedly unfriendly.19 In general, character may not be proved in order to

17 FED. R. Evw. 405(a) and 608(b) specify that cross-examination may be permitted regarding specific conduct. In Michelson v. United States, 335 U.S. 469 (1948), the Supreme Court approved the prosecution's questioning the defendant's character witnesses about the defendant's prior arrest. As a basis for this result, the Supreme Court explained that the prosecution must be allowed to test the qualifications of the character witness. If the witness had not heard of the arrest, reasoned the Court, he might not be well qualified to testify as to general reputation. Id. 483; see also McCormrck, supra note 4, §191, at 456-57 \& n.73.

18 Wigmore argues strongly for a return to the use of opinion evidence instead of reputation evidence:

The Anglo-American rules of evidence have occasionally taken some curious

twistings in the course of their development; but they have never done anything so curious in the way of shutting out evidential light as when they decided to exclude the person who knows as much as humanly can be known about the character of another, and have still admitted the secondhand, irresponsible product of multiplied guesses and gossip which we term "reputation."

7 WIGMORE, supra note 2, $\$ 1986$ (Chadbourn rev. 1978) (footnote omitted).

Greenleaf similarly expressed a preference for proof by opinion rather than by reputation evidence: "It is to be regretted that the orthodox practice [using opinion testimony] has been departed from, for it furnished the most satisfactory mode of learning a witness' character." I GREENLEAF, supra note $8, \S 461$ (c).

Early English common law preferred the use of opinion evidence to establish character. The witness testified to his or her personal belief, based on personal knowledge, about the character of the defendant or other witness. Testimony concerning particular acts was generally not permitted, although it was more likely to be admitted concerning the defendant than a witness.

American courts took the opposite path, relying on reputation evidence rather than personal opinion to prove moral character. Wigmore attributes this divergence to a misunderstanding of English precedent which was given credence by Chief Justice Swift of Connecticut in his treatise on evidence in 1810. 7 Wramore, supra note 2, $\$ 1981-1985$ (Chadbourn rev. 1978). In Michelson, 335 U.S. at $475-87$, the Supreme Court discussed the inconsistencies and illogic of the common law rules, but declined to change them. See supra note 17.

10 FED. R. Evm. 404 explicitly states: "Evidence of a person's character or a trait of his character is not admissible for the purpose of proving that he acted in conformity therewith on a particular occasion ...."

Scholars and courts continually accept and justify this rule. Wigmore claims that the bar on propensity evidence to show that the defendant acted in accordance with character has been so often repeated as to be "commonplace." I WIGMone, supra note 2, 192 (3d ed. 1940). Similarly, in People v. Molineux, 168 N.Y. 264, 291, 61 N.E. 286, 293 (1901), the court notes: 
establish conduct consistent therewith. A number of exceptions to this rule of rejection provide the element of anomaly that we shall seek here to explore. First, however, let us put aside one obvious case sometimes mistakenly classified as an exception.

Occasionally, some trait of character is directly in issue as a substantive element of a charge, claim, or defense, and character evidence of the "trace" variety is received to establish the trait in question. $^{20}$ If, for example, a plaintiff sues the defendant for defamation by having called the plaintiff a swindler and a thief, the plaintiff must prove that honesty and fair dealing were his true characteristics, while the defendant may wish to show larcenous traits. Direct proof of the character fact in issue may be had from witnesses upon whom the plaintiff's character had left its mark, one way or another. People who knew the plaintiff may state their opinions of his character with respect to honesty in financial matters; those who knew his reputation in this regard may report it; and (in a pretty inversion of the conduct-character inference) some jurisdictions ${ }^{21}$ and the federal rules ${ }^{22}$ will permit witnesses to recite instances of the plaintiff's unrelated financial dealings from which the character trait in issue might be inferred.

These direct or circumstantial trace-proofs of the trait of character itself, as the substantive fact in issue, do not concern us here.

The general rule of evidence applicable to criminal trials is that the state cannot prove against a defendant any crime not alleged in the indictment, either as a foundation for a separate punishment, or as aiding the proofs that he is guilty of the crime charged. . . . This rule, so universally recognized and so firmly established in all English-speaking lands, is rooted in that jealous regard for the liberty of the individual....

Greenleaf concurs, citing unfair prejudice and confusion of the issues as the reasons justifying the rule. 1 GREENLEAF, supra note $8, \S 14 \mathrm{a}-\mathrm{b}$. McCormick also notes the persistence of this rule and its underlying policies: "The reason for the general rule is that character when used for this purpose is not essential as it is when character is the issue, and generally it comes with too much dangerous baggage of prejudice, distraction from the issues, time consumption, and hazard of surprise." MCCorarcK, supra note $4, \S 188$, at 445 (footnote omitted).

${ }^{20}$ See 1 Wigmore, supra note 2, $\$ 54$ (3d ed. 1940); see also 1 GREENLEAF, supra note $8, \S 14$ (d) (Character is often, by the substantive law of the case, a part of the issue, and is not used as tending to prove any other fact. In such a case, the admission involves only a question of that substantive law, and not a question of evidence.).

21 MCCoRmick, supra note $4, \S 187$ (proof by specific acts allowed in many common law jurisdictions; such evidence is most likely to create prejudice and hostility, but is also most probative).

22 FED. R. EvID. 405(b) ("In cases in which character or a trait of character of a person is an essential element of a charge, claim, or defense, proof may also be made of specific instances of conduct."); see also 1 WIGMORE, supra note 2, $\$ 202$ (3d ed. 1940) (justifying specific conduct evidence when character is in issue by noting that the problems of undue prejudice, unfair surprise (to a degree), and confusion of issues are less present; also emphasizing the practical necessity for allowing the use of such evidence). 
Instead, we focus on the rule disallowing proof of a person's character as an intermediate evidentiary fact from which an ultimate fact in issue-the person's conduct-may. be inferred. ${ }^{23}$ Here, we discover three true exceptions to the general ban that may be of interest: The first permits some proof of pertinent traits of character in criminal cases; the second addresses character evidence as a means of impeaching a witness's credibility; and the third is a special purposes exception deserving particularly close scrutiny.

\section{B. Criminal Trial Exceptions}

\section{Character of the Defendant}

As a true exception to the rule against the proof of conduct by inference from character, a criminal defendant traditionally may prove a trait in his own character from which the factfinder might derive a reasonable doubt that the defendant committed the charged criminal act. ${ }^{24}$ The trait itself is proved, of course, by some trace method. But its relevance is found in the assessment that its establishment makes less likely the occurrence of the specific item of behavior attributed to the defendant either by the indictment or by the witnesses against him. Logically, therefore, the trait of character offered by the defendant should be closely or strongly related to the criminal behavior in issue: the conduct charged to the defendant must be thought a very rare occurrence in persons of the described character. ${ }^{25}$ For example, a defendant accused of larceny by fraud or deceit may submit proof that he is reported or believed

23 Some writers refer to this use of character evidence as "circumstantial." See, e.g., McCormrck, supra note $4, \S 188$, at 444 . While I can appreciate the use of the term in the sense of "indirect" I think there is some possible confusion because character directly in issue may also be-and indeed, is normally-proved "circumstantially."

24 See, e.g., United States v. Staggs, 553 F.2d 1073 (7th Cir. 1977); FED. R. Evm. 404(a)(1). Wigmore explains: "A defendant's character, then, as indicating the probability of his doing or not doing the act charged, is essentially relevant." I WIGMORE, supra note $2, \$ 55$, at 450 ( $3 \mathrm{~d}$ ed. 1940 ) (emphasis in original). Because the policy considerations of confusion of the issues, unfair surprise, and undue prejudice are not present with regard to the defendant's character, Wigmore concludes that a defendant may always offer evidence of good character. Id. \$55-56; see $2 \mathrm{~J}$. Weinstein \& M. Berger, Weinstein's Evidence $\int 404$ [5] (1981) (accused has an absolute right to introduce character evidence) [hereinafter cited as Wenssters]. Note, however, that the evidence offered by the defendant of a pertinent trait must be either by opinion or reputation testimony; proof of specific instances is allowed only on cross-examination. FED. R. Evm. 405(a).

${ }^{25}$ McCormick states that "[a] few courts permit proof of "general good character" but the prevailing and more practical view limits the inquiry to the trait or traits involved in the crime on trial-honesty in theft cases, peaceableness in murder, and the like." McConMrck, supra note $4, \$ 191$, at 455 (footnotes omitted). The advisory committee's citation to McCormick indicates its intention that FED. $R$. Evm. 404 be so limited. FED. R. Evm. 404 advisory committee note. 
to be open and honest in dealings concerning money and property. Having elected to submit proof of this sort, of course, the defendant will not be heard to object to rebuttal evidence of the same naturealbeit to contrary effect-adduced against him. ${ }^{26}$

Thus, subject only to the restriction that the trait to be proved be inconsistent with the conduct charged, the criminal defendant becomes the only person in court entitled to benefit from the ordinary understanding that behavior springs from the nest of personality. The defendant in a criminal case is likely to be seeking a negative inference, to be sure, but the process of reasoning to a negative conclusion is no different than to the positive. The defendant, by showing his traits of caution and sensitivity to consequences, asks the factfinder to infer that he did not act with reckless indifference to human life on the occasion in question. The logic is obvious: the character trait of "cautious" is assigned by repeated observation of various incidents in which the subject demonstrated what most of us would term careful conduct; add the assumption that such examples truly represent a central trait of character that will dictate future behavior of the same sort, given the appropriate circumstances for it; Q.E.D.- he would not have acted recklessly on the occasion in issue. If the prosecutor seeks to respond by proving the traits of negligence and thoughtlessness to obtain the positive inference the element of proof demands, he does so by means of the identical logical chain, but may do so responsively only.

Just why the defendant in a criminal case should enjoy the exceptional opportunity to disprove alleged conduct by evidence of his own good character is far from clear. ${ }^{27}$ It is not that a person's reputed trait of attentive care might not have some bearing on a charge of reckless endangerment. It might be highly probative. ${ }^{2 s}$ But surely no more so than it would be in a suit rather than a prosecution for gross negligence. Despite the tempting analogy, it probably cannot be truly said that the exception derives from the ancient trials by oath and compurgation, ${ }^{29}$ for it seems clear that

26 See FED. R. Evm. 404(a)(1); United States v. Davenport, 449 F.2d 696 (5th Cir. 1971).

27 See Note, Other Crimes Evidence at Trial: Of Balancing and Other Matters, 70 YALE L.J. 763, 780 (1961).

28 See McCormacs, supra note $4, \$ 188$.

29 Trial by oath consisted of the sworn statement of denial by the defendant (or sworn statement by the plaintiff denying the defendant's affirmative plea). In trial by compurgation, the defendant produced "oath-helpers," or compurgators, to attest to his or her veracity. The compurgators simply swore that they believed the defendant to be telling the truth. They were neither required nor expected to testify about the underlying facts. This method of trial was also called trial by wager of law. See 3 W. Blackstone, Commentaries on the Laws of ENGLAND 
evidence of good character for veracity was admitted to support the sworn denials of a party in a civil suit as well as the criminal defendant. ${ }^{30}$ So too, the restriction of the exception to character of the defendant himself seems illogical. The critical issue in a defense of a civil or criminal trial may be the conduct of a person other than the defendant, and evidence relating to this person's character may be highly relevant. If the state alleges, for example, that an uncharged coconspirator or a severed accomplice harbored the defendant and assisted his escape, the defendant may wish to show that the person in question had the reputation of a law-abiding person or perhaps had on other occasions assisted in the capture of fleeing felons. By what tenable theory is this line of defense closed? About the best one can do with this puzzle is to guess that somewhere, somehow the rule was relaxed to allow the criminal defendant with so much at stake and so little available in the way of conventional proof to have special dispensation to tell the factfinder just what sort of person he really is. ${ }^{31}$ Unfortunately, dispensations of this sort do little to improve the logical coherence of the rule, however charitably intended.

\section{Character of the Victim}

The special considerations of criminal defense permitting the defendant to assert his own good character are not sufficient justifications for the other half of the exception applicable to criminal cases: the defendant may also prove "pertinent traits" of the victim's character, ${ }^{32}$ despite the fact that such proof of the victim's bad character may damage a person who has not voluntarily " "plac[ed] his [or her] character in issue." "33 By "pertinent," we can probably assume that the federal rule means "relevant" (though what nuance they sought to convey by shifting the term, I cannor guess),

341-44 (4th ed. 1770); 2 F. Pollock \& F. Martland, The History of ENGlish

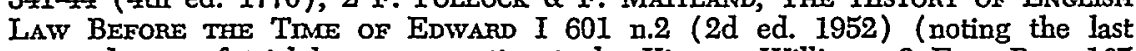
reported case of trial by compurgation to be King v. Williams, 9 Eng. Rep. 167 (1824)).

30 Trial by compurgation, unlike its surviving descendant, was not limited to criminal cases. Indeed, Blackstone implies that trial by oath was not permitted in certain criminal cases, at least not those relating to force or violence. See W. BLACKstone, supra note 29, at 346 . But see F. Polrock \& F. MarrLaNd, supra note 29, at 635 .

31 See FED. R. Evm. 404(a) advisory committee note.

32 FED. R. Evm. 404(a)(2) permits the accused to offer evidence of a pertinent trait of character of the victim. See also 1 GREENLEAF, supra note $8, \$ 14(\mathrm{~b})$; 1 WIGMORE, supra note $2, \$ \$ 198-200$ (3d ed. 1940).

33 While this phrase is often used in "courtroom parlance," it is misleading. See McCormick, supra note 4, $\$ 191$, at 454-55. 
and by "relevant" the old rule meant some characteristic mode of behavior that, had the victim acted in accord therewith, would have diminished or cancelled the culpability of the defendant. Thus (theoretically, at least) ${ }^{34}$ a defendant accused of bribing a public official might show that the official in question had exhibited the trait of greed or abuse of power in order to advance a defense of extortion. Perhaps a person accused of "joyriding" might be able to prove the owner's characteristic trait of generosity to support his claim that he was operating the car with the permission of the owner. Among the many examples of "pertinent" traits, two deserve special mention, for they are at once the most commonly cited and, in many ways, the strangest.

\section{a. For Aggression}

By ancient and common usage, a person defending a charge of physical aggression-from assault to homicide-may prove that his victim was a quarrelsome or violent person to support the claim of self-defense. ${ }^{35}$ This evidence might support the inference that the defendant had reason to be fearful of the victim or that the victim might have been the first aggressor in the disputed incident. The main point of divergence among the jurisdictions seems to be whether, to be admissible, the victim's aggressive reputation had to be known to the defendant. ${ }^{36}$ The majority view is that the characteristic is relevant regardless of the defendant's appreciation of it. $^{37}$ For our purposes, the significance of this view is that it most clearly illustrates the foundation of relevance, to wit: evidence of character tends to prove conduct (that is, initial aggression against

34 Although the common law rule is as broad as FED. R. Evm. 404(a)(2), it is difficult to find examples of the use of a victim's character in any cases except homicide/assault and rape. See Annot., 1 A.L.R.3d 571 (1965); Annot., 140 A.L.R. 364 (1942).

35 See MCCormuck, supra note 4, \$193; 2 WEINSTEIN, supra note 24, I 404 [06]; 1 WIGMORE, supra note 2, $\$ 63$ (3d ed. 1940). Each of these treatises speaks primarily of using evidence of the victim's character in homicide cases. Although use in homicide cases is emphasized, use is apparently also permitted in assault cases. See Annot., I A.L.R.3d 571, 577 (1965).

30 Wigmore distinguishes between evidence of the victim's violent character to prove that he acted in conformance in the specific incident and evidence of the communication of the victim's character for violence to show the reasonableness of the defendant's apprehension of violence. For the former, knowledge by the defendant is unnecessary. For the latter, knowledge clearly is essential to the claim. 1 Wigmore, supra note $2, \$ 63$ ( $3 \mathrm{~d}$ ed. 1940). McCormick makes the same distinction. MCCormTCK, supra note $4, \$ 193$, at 961 n.99.

37 McCormick, supra note $4, \$ 193$. McCormick writes: "It is almost universally held that when such evidence [that the accused had attacked first] has been produced the accused may introduce testimony of the reputation of the deceased for turbulence and violence." Id. $\$ 193$, at 461 (footnote omitted). 
the defendant) in accord therewith. The minority, while admitting the evidence to show that the defendant, knowing the aggressive reputation of the victim, might have been fearfully apprehensive, nonetheless disavows the relevance of the evidence of character as proof of actual aggressive conduct by the victim on the occasion at issue. A New York court, for example, states: "Such evidence is not received to show that the deceased was the aggressor, for if competent for that purpose, similar evidence could be given as to the reputation of the defendant as bearing on the probability that he was the aggressor." 38 The Federal Rules of Evidence, it might be noted, are squarely aligned with the majority rule; because the victim's aggressiveness is clearly "pertinent" to a defense of responsive attack, the federal rules classify it as an enumerated exception to the rule against the use of character evidence to prove consistent conduct. ${ }^{39}$

Rule 404(a)(2) goes somewhat further. In the highly particular instance of a homicide prosecution in which defense evidence has been offered that the victim was the "first aggressor," the prosecution may offer evidence that the victim was "peaceful" by temperament. The exception relating to the character of the victim is thereby extended because the evidence of character may come from the state in the first instance, rather than as rebuttal for evidence of the same nature first presented by the defense. Presumably, the extension is deemed acceptable for the special reason that in such cases, the dead victim is not available to attest to his own peaceable behavior during the encounter in question. Be that as it may, we note that the federal rule's extended exception allows for the admission of proof that the victim acted in accordance with certain character traits during the incident in question.

\section{b. For Unchastity}

Until recently, a second classic example of the permissible proof of character by a criminal defendant to prove conduct consistent therewith was the exception extended to the man defending against a charge of rape by alleging consent of the victim. As originally adopted, the federal rules contemplated admitting a defendant's evidence of the victim's character, ${ }^{40}$ and the advisory

38 People v. Rodawald, 177 N.Y. 408, 423, 70 N.E. 1, 5-6 (1907).

$39 \mathrm{FED}$. R. Evm. 404(a)(2). But see infra notes 40-52 and accompanying text (discussion of FED. R. Evm. 412 modifying general rule for rape victims).

$40 \mathrm{It}$ is difficult (and fortunately moot) to describe just how the original formulation would have defined "pertinent traits" of the rape victim's character. We 
committee's note so states. ${ }^{41}$ Three years later, however, the assumptions underlying that rule were seriously reconsidered, ${ }^{42}$ with the result that the federal rules, ${ }^{43}$ as well as other coded and uncoded versions of the rule, ${ }^{44}$ have been replaced by a rather complex formulation. 45

In brief, rule 412 , governing both the admissibility of evidence of the rape victim's character and permissible modes of proof, prohibits the introduction of reputation or opinion evidence concerning the rape victim's past sexual behavior. ${ }^{46}$ Specific conduct evidence is also excluded, except in three situations. Specific conduct evidence may be admitted to show that someone other than the defendant was the source of semen or injury ${ }^{47}$ or, on the issue of consent, to show that the victim previously had engaged in sexual behavior with the defendant. ${ }^{48}$ Finally, specific conduct is admissible when exclusion would violate the defendant's constitutional rights. ${ }^{49}$. During congressional debate, Congressman Mann explained this exception: "The first circumstance is where the Con-

suppose that in a bygone era, words like chastity or promiscuity had clear meaning and obvious relevance to the issue of whether a woman had consented to sexual penetration on the occasion in issue. Although possible, it seems unlikely that the same set of assumptions guided the draftsmen of the Federal Rules of Evidence in an era of "loose morals," when such labels may not be as probative on the issue of sexual choice in a given situation. As originally formulated, the rule and accompanying note give no hint whether an accused rapist could support his defense of consent by showing that the victim had the trait or reputation of a multi-lovered woman, a sexual adventuress, or what. See FED. R. Evro. 404(a)(2) \& advisory committee note. While speculation on the matter is possible, it is unnecessary to reach a conclusion, thanks to the sound-though tardy-work of reform. See FED. R. Evm. 412.

41 FED. R. Evm. 404(a)(2) advisory committee note ("an accused may introduce pertinent evidence of the character of the victim, as in support of a claim of ... consent in a case of rape").

42 The lobbying efforts of feminist groups have generally been seen as the cause of this sudden awakening of legislative sensitivity. See Berger, Man's Trial, Woman's Tribulation: Rape Cases in the Courtroom, 77 ColUM. L. REv. 1, 31-32 (1977). The critical comments of scholars also may have precipitated this change. See, e.g., Ordover, Admissibility of Patterns of Similar Sexual Conduct: The Unlamented Death of Character for Chastity, 63 CoRnel. L. REv. 90 (1977).

43 Congress enacted FED. R. Evm. 412, restricting the use of the victim's past sexual behavior in a rape trial, on October 28, 1978, making it applicable to trials beginning more than thirty days after that date. See Privacy Protection for Rape Victims Act of 1978, Pub. L. 95-540, \$ 3, 92 Stat. 2046.

44 For a compilation of state statutes and commentary on their various formulations, see Tanford \& Bocchino, Rape Victim Shield Laws and the Sixth Amendment, 128 U. PA. L. Rev. 544 (1980).

45 See, e.g., FED. R. Evm. 412.

46 FED. R. Evid. 412(a).

47 FED. R. Evm. 412(b)(2)(A).

48 FED. R. Evm. 412(b)(2)(B).

49 FED. R. Evm. 412(b)(1). 
stitution requires that the evidence be admitted. This exception is intended to cover those infrequent instances where, because of an unusual chain of circumstances, the general rule of inadmissibility, if followed, would result in denying the defendant a constitutional right." 50

I find the Congressman's comment as mystifying as the provision itself. What could he, and the drafters, have had in mind? The only constitutional right to proof that I am aware of comes through the sixth amendment's confrontation clause, understood to mean full cross-examination. ${ }^{51}$ Other constitutional rights-notably to the assistance of counsel, to compulsory process, and to a fair trial-yield readily to ordinary rules of evidence precluding admissibility. Surely, Congress did not mean by this proviso that the constitutional right to cross-examination entitles the rape defendant to ask his victim about her prior sexual activities as conduct evidencing character relevant to consent. Such a construction would have returned the law to the point where it was under rule 404(a)(2). In a sense, the whole point of the enactment of rule 412 was to change the law of relevancy concerning "sexual character." If Congress believed-and correctly believed-that the constitutional right of confrontation overcomes such legislative modifications of the rule of relevancy, the position spells serious trouble for the law of character evidence, and indeed for many other provisions of the federal rules as applied to defendants in criminal cases. I prefer to believe that the proviso contemplated no such sweeping interpretation of the right to confrontation. And I am fortified in my belief by Congressman Mann's assurance that the clause in rule 412 would apply only in rare cases. ${ }^{52}$

50124 Cong. Rec. H11,944 (daily ed. Oct. 10, 1978).

Even where evidence would be admitted under one of the exceptions, Fen. R. Evm. 412 (c) (3) gives the court power to exclude it if its prejudicial value outweighs its probative value. See 124 Cong. REc. H11,945 (daily ed. Oct. 10, 1978) (statement of Congresswoman Holtzman, drafter of FED. R. Evm. 412). The rule also details stringent notice requirements and a pretrial hearing procedure. FED. R. Evm. $412(\mathrm{c})(1)-(\mathrm{c})(3)$.

While unusually long and detailed on its face (compared with other rules), zule 412 has no advisory committee note or other committee reports. Nor does the new rule boast much in the way of judicial construction. One reason for this latter dearth may be the rarity of rape cases in federal courts. For brief discussions of rule 412 , see 2 D. Lovisell \& C. MuELLER, FEDERAI Evmence $\$ \$ 197-199$ (Supp. 1981); Tanford \& Bocchino, supra note 44, at 551-53.

51 See, e.g.; Davis v. Alaska, 415 U.S. 308 (1974); Smith v. Illinois, 390 U.S. 129 (1968).

52 See supra text accompanying note 50 .

The question remains, then, what infrequent and unusual "chain of events" might raise the supervening constitutional right of inquiry into the otherwise prohibited subject matter? I can only imagine cases where the victim had gratuitously 


\section{Credibility Exceptions}

If the primary behavioral issue at trial is the conduct of the important actors during the past event in question, the secondary issue is the behavior of the witnesses on the stand. This secondary issue is usually called "credibility," though the issue might be more properly termed "veracity"-not whether the testimony is believable but whether it is true. Although $I$ have put this question in second place, I certainly do not disparage its importance. It is often the only key to the mystery of the "primary" issue, and rightly receives the most devoted attention of all concerned in the process. To assist in the necessary resolution of this difficult trial issue, the law of evidence allows another exception to the rule against reference to character as a predictor of conduct: in specified instances character evidence is admissible to impeach a witness. ${ }^{53}$ Consistent with the "pertinent trait" limitation applicable to character evidence generally, evidence of character offered to enlighten the secondary issue is restricted to the trait of truthfulness. ${ }^{54}$ Apart from this consistency, evidence of character pertaining to a testifying witness has some distinctive features.

According to general practice and the federal rules as they finally evolved, extrinsic evidence of general "truthfulness" may be adduced by reputation or opinion concerning the character of any witness who testifies. ${ }^{55}$ Here, however, unlike the case of character evidence regarding some other "pertinent" trait, the evidence of good repute cannot be introduced until character has been attacked, either by evidence of bad reputation or opinion, "or otherwise" (presumably by cross-examination suggesting untruthfulness). The oddity here is that, despite major impediments to a rule of admittance such as the avowed distrust of propensity evidence, the serious danger of multiple byways to distract the factfinder's attention, and the evident weakness of reputation evidence on a trait often inexactly termed "honesty and integrity," 50 the law generally and

asserted prior chastity or fidelity, or possibly ignorance of the physiology of sexual contact. As such, the proviso might have been better put in terms of relevant rebuttal (which might otherwise count as an unwise omission from the reserved allowances), but the clause need not otherwise detain us.

63 FED. R. Evw. 608.

54 Compare FED. R. Evm. 404(a)(1)-(2) with FED. R. Evw. 608(a) (similar limitations on admissibility of character evidence).

55 See FEo. R. Evm. 608(a); McConMrcx, supra note 4, $\$ 42$.

56 For a discussion of the additional problems caused by our careless usage of generalized character terms and the inherent narrowness of these categories, see supra note 7 and accompanying text. 
perhaps universally tolerates it. ${ }^{57}$

The policy strong enough to overcome the obvious problems with such evidence is doubtless the feeling that the hapless factfinder has little enough to go on in evaluating the veracity of a stranger, usually testifying on an unfamiliar subject, in the strange and artificial role of courtroom witness. Some sense of the witness's reputation for credibility among those who know him is a necessary and reasonably fair guide. Compurgation may still have its uses, 58 and a good name still counts for something when other indicia of credibility are indistinct. And avow it or not, we do believe that the person thought by his peers to be honest in a variety of unrelated ways is more likely than a person randomly picked from the general run to behave in accordance with that virtuous characteristic when he is seated on the stand and testifying under oath. The converse appears even more sensible-a witness's general reputation as a liar should be taken into account when considering his veracity on a particular subject of importance. This conclusion simply relies on the common belief that character counts, despite the law's general refusal to acknowledge it openly.

The distinction between evidence of character bearing on a witness's truthfulness and evidence of character generally has been sharpened by the federal rules, at some cost in comprehension. The draftsmen elected to transport the rules as applied to matters of credibility from article 4 ("Relevancy and Its Limits") to article 6 ("Witnesses"). In doing so, the rules leave two somewhat different provisions applicable to character evidence as adduced for or against a witness: rules 405 and 608 .

While drafting cavils could occupy us for pages, one inconsistency resulting from the chosen form is serious. It concerns the great variable factor in these equations: proof of specific conduct. Rule $405(\mathrm{~b})$, insofar as pertinent, allows that "proof may . . . be made" of specific instances of conduct where character or a trait is "an essential element of a charge, claim, or defense." Reading this section alone, a lawyer might be forgiven for thinking that, if he is defending on the theory that an adverse witness is fabricating

57 FED. R. Evm. 608(a); McCorMuck, supra note 4, $\$ \$ 44,194 ; 3$ WeINSTEN, supra note 24, โ608[03]; 3A WIGMORE, supra note 2, \$922, at 726 (Chadbourn rev. 1970) ("Character for truth is always and everywhere admissible.").

Of course, additional considerations may underlie this rule. Bolstering credibility when not disputed may waste precious time and may influence the factfinder to decide on the basis of a party's "good and truthful" witnesses, regardless of what they say. See FED. R. Evm. 608(a) advisory committee note; MicCorMICK,
supra note $4, \S 49$, at $102 \&$ n.73.

58 See supra notes 29-30 \& accompanying text. 
his story out of vindictive and malicious bias, he may inquire, and lacking satisfaction, offer extrinsic evidence to prove that the witness had previously brought an unfounded claim or charge against the same defendant.59 The phrase "essential element of a ... defense" must in some cases include a matter of veracity. Yet looking at rule $608(\mathrm{~b})$, it turns out that, on the question of credibility, specific instances of the witness's prior conduct may not be proved by extrinsic evidence, even if they are clearly probative of truthfulness or the lack of it.

Pursuing further the use of specific instances of prior conduct as demonstrations of character (and thence as evidence of the conduct of the witness on the stand), we encounter one of the major anomalies in the picture. Normally, and under the federal rules, ${ }^{60}$ extrinsic evidence will not be received concerning prior instances of conduct by a witness, however well they may reveal the relevant trait of truthfulness. ${ }^{61}$ Diogenes himself would be removed from the stand if he tried to recount the deed of a prior witness so clearly bespeaking a love of truth that it convinced the old man to put down his lantern at last. Even by cross-examination, the allowance of prior acts bearing on credibility is limited.62 In the court's discretion (Congress was careful to emphasize), ${ }^{63}$ and only where

59 I grant that FED. R. Evm. 405(b) does not say in so many words that proof may be made by extrinsic evidence to impeach a witness's testimony that is an essential element of a defense, but I think this is a plausible implication, particularly because subsection (a) mentions cross-examination explicitly when that is the exclusive allowable time for the use of specific instances evidence. But see FED. R. EVID. 405 advisory committee note (stating that specific instances "is not generally permissible" for impeachment).

60 FED. R. Evm. 608(b).

61 Wigmore states that no bar to proof by extrinsic evidence existed prior to the 1700 's, but that after the early 1700 's courts began prohibiting such evidence, primarily because it confused the issues and surprised the opponent. 3A WrGmore, supra note $2, \$ 979$ (Chadbourn rev. 1970).

McCormick, in accord with Wigmore, explains that the general requirement that "the examiner must take his answer" means that the examiner may not call other witnesses to prove the prior acts, though he may further cross-examine the witness. McCormack, supra note 4, $\S 42$; see also 3 WeInsten, supra note 24 , I $608[05]$.

62 Note that specific instances of conduct are always admissible on crossexamination, see FED. R. Evro. 404, 405(a), and sometimes admissible on direct, see id. $405(\mathrm{~b})$, to proye that a criminal defendant or a victim has acted in accordance with specified traits.

63 The second sentence of FED. R. Evw. 608(b) begins: "[Specific instances of the conduct of a witness] may, however, in the discretion of the court, if probative of truthfulness or untruthfulness, be inquired into on cross-examination of the witness ...." The House committee amended the rule to emphasize the discretionary power of the court in determining the scope of such testimony. H.R. REP. No. 650, 93d Cong., 2d Sess. 10, reprinted in 1974 U.S. Code Cong. \& AD. NEws 7075, 7084 . 
the prior acts are truly probative of veracity, the witness may be asked about his own prior dishonest conduct. ${ }^{64}$ Or, a witness attesting to the good reputation of some other witness may be asked if he had heard of, or considered certain dishonest behavior of, the witness whose honesty he had just endorsed. This last exception is a special case from our present perspective, because it does not introduce prior conduct as proof of character to predict behavior in accordance therewith, but rather serves to undermine the expert status of the character witness by showing either that he had insufficient data for his opinion, or that he had erroneously weighed the data he had. For our purposes, it is sufficient to note that, with one limited exception, the rule regarding impeachment by prior misconduct, like the rule regarding misconduct as proof of character generally, appears-thus far-to be resolutely negative.

This stance of apparent refusal, however, rests upon ground thoroughly undermined by a rule so devastating as to make a mockery of the bar against specific instances of conduct. Too important and too vast to be called an exception, the rule I refer to is the allowance of impeachment by proof of previous conviction. ${ }^{65}$ The rule has had an interesting career. Softened by case law in the District of Columbia ${ }^{66}$ it was hardened again by statute, ${ }^{67}$ only

64 Paragraph two of FED. R. Evm. 608(b) states: "The giving of testimony, whether by an accused or by any other witness, does not operate as a waiver of his privilege against self-incrimination when examined with respect to matters which relate only to credibility." The purpose of this provision, which the advisory committee felt was necessary from both constitutional and policy perspectives, is to encourage witnesses to testify without fearing the disclosure of incriminating facts irrelevant to the material facts of the case. 3 Wensstens, supra note 24, I608[07]; see 8 WrgMone, supra note 2, $\$$ 2276-2277 (McNaughton rev. 1961); MCCorMack, supra note 4, $\$ 42$. FED. R. Evm. 608 (b) does not, of course, prohibit inquiry into prior acts for purposes other than credibility. Under FED. R. Evm. 404(b), for example, evidence inadmissible on the issue of credibility would be admissible to show proof of motive, opportunity, intent, preparation, plan, knowledge, identity, or absence of mistake or accident. See infra text accompanying notes 110-13.

65 See FED. R. Evm. 609. See generally Cohen, Impeachment of a DefendantWitness by Prior Conviction, 6 CarM. L. BuLc. 26 (1970); Glick, Impeachment by Prior Convictions: A Critique of Rule 6-09 of the Proposed Rules of Evidence for U.S. District Courts, 6 Crus. L. Boll. 330 (1970); McGowan, Impeachment of Criminal Defendants by Prior Convictions, 2 LAw \& Soc. Ord. 1 (1970); Spector, Impeaching the Defendant by His Prior Convictions and the Proposed Federal Rules of Evidence: A Half Step Forward and Three Steps Backward, 1 LoY. U. Cㅍ. L.J. 247 (1970); Impeachment Under Rule 609(a): Suggestions for Confining and Guiding Trial Court Discretion, 71 Nw. U.L. REv. 655 (1976) [hereinafter cited as Symposium]; Note, supra note 27.

66 The oft-cited case of Luck v. United States, 348 F.2d 763 (D.C. Cir. 1965), stressed that the introduction of prior convictions for impeachment was an area for the exercise of judicial discretion. The Luck court suggested relevant factors in the determination: the nature of the prior crimes, the length of the criminal record, the age and circumstances of the defendant, and the extent to which it is more important to the search for truth in a particular case for the jury to hear the defendant's story than to know the prior conviction. Id. 769. 
to develop a variety of modifications in various state jurisdictions (by judicial and legislative efforts), ${ }^{88}$ and then to receive a careful restyling in federal rule 609. In all shapes and forms, the rule remains capricious at best, more likely pernicious in the criminal process, and probably equally injurious to justice when applied on the civil side. A major task of this Article will be to argue that the rules of evidence governing the admissibility of characterbespeaking conduct generally, and convictions in particular, are just the reverse of what logic and good sense would commend.

How did we come by this legal axiom allowing severe credibility impeachment by the unadorned fact of a prior conviction against the general scorn for evidence of prior misconduct? Perhaps the simplest answer is the purely mechanical one: unlike prior misconduct generally, prior criminal conviction may be easily proved extrinsically from public records. ${ }^{69}$ Three strikes, however, may be pitched against this appealing theory. First, we do not normally compose rules - nor should we-in the delicate balance of pertinence and digression solely on the crude basis of documentary availability. In many cases, trial issues may be as readily confused, time as easily wasted, and net gain as uncertain by the introduction of a purported official computer printout "record" as by a witness's description of other specific bad acts. Moreover, a witness challenged by his conviction may well try to introduce evidence to contradict or amplify the record, thereby destroying any claim of neatness of proof. Second, although the designation "official record" may overcome hearsay objections to its admission, ${ }^{70}$ it is no guarantee of

A few years later, in Gordon v. United States, 383 F.2d 936 (D.C. Cir. 1967), cert. denied, 390 U.S. 1029 (1968), Chief Justice (then Judge) Burger elaborated on Luck, creating a more extensive list of factors: the nature of the past crimes, the time of conviction and the witness's subsequent history, the similarity between the past crime and the crime charged (crimes with great similarity to the one charged should be sparingly admitted because of the impermissible propensity inference), the importance of the defendant's testimony, and the certainty of the credibility issue. Id. 940 .

67 In 1970, Congress reacted to Luck and Gordon by amending $\$ 14-305$ of the District of Columbia Code, Pub. L. No. 91-358, 84 Stat. 473 (1970), to remove discretion from the judge and to allow the unchallenged introduction of felonies, without regard to the nature of the offense, and crimen falsi, without regard to the grade of the offense. See FED. R. Evm. 609 advisory committee note. The statute was upheld in Dixon v. United States, 287 A.2d 89 (D.C.), cert. denied, 407 U.S. 926 (1972).

\section{See generally McCormar, supra note 4, $\$ 43$.}

69 The federal rules explicitly allow evidence of certain prior convictions to attack credibility, but only if elicited from the witness or extrinsically "established by public record."

70 FED. R. Evm. 803(8). 
accuracy, as every practitioner in the criminal courts knows. Further, the very fact that it is called "official" unduly underwrites its supposed validity. Third, what the record actually says-even if clear, complete, and accurate-is often of very little value concerning the criminal conduct supposedly relevant to the credibility of the witness. What can a conscientious lay factfinder learn from a sheet that says a person was arrested and charged with assault and robbery and convicted of the attempted possession of a weapon? Or, if the charge at arrest is "redacted," does the record speak to credibility when it informs the jury that a witness was convicted of unlawful possession of stolen property in the second degree? And these are examples that at least boast crimes with generally understood names. ${ }^{71}$

Because the efficiency argument can hardly be a completely satisfying explanation, we might next try to derive the rule's purpose from its development. Witnesses, in the modern sense, were invented during the sixteenth century, ${ }^{72}$ but it is only in the last hundred years that persons previously convicted have been permitted to testify under oath. ${ }^{73}$ As with a number of other conclusive presumptions of incredibility, ${ }^{74}$ evolution was (and continues to be) from rejection to relevancy. ${ }^{75}$ The distrust of the witness, which barred testimony for three centuries or more, continues to govern the rule, but rather than spelling incompetence, it now produces a mere presumption of relevance to veracity. ${ }^{76}$ Thus, today we have advanced to the point where we can say to the previously convicted witness: you may testify but the jury charged with evaluating your honesty may, and doubtless will, consider

71 One can imagine the lack of enlightenment from a record showing previous convictions for "RICO," "Conspiracy," and "Travel Act."

72 See 9 W. Hornsworth, A Hustory of ENGLISH LAw 178 (3d ed. 1944).

73 See McCormack, supra note 4, $\$ 64$; Ladd, supra note 11, at 174-75. The common law disqualification was finally revoked in federal courts in 1917. Rosen v. United States, 245 U.S. 467 (1917).

74 McCormick describes a number of them: immaturity, mental incapacity, lack of belief in a retributive divine being, and being a party, other interested person, or spouse of the same. McCormack, supra note 4, $\$ \$ 62-63,65-66$.

75 Some disqualifications, notably the "dead man's statute," are still being reformed. In this instance, however, the usual evolutionary pattern has been ignored by codemakers who simply abolish the old refusal to hear the survivor's version of the transaction with the deceased. See id. $\$ 65$.

76 See Greenlear, supta note $8, \S 372$, at 513 ("The basis of the rule seems to be that such a person is morally too corrupt to be trusted to testify; so reckless of the distinction between truth and falsehood and insensible to the restraining force of an oath, as to render it extremely improbable that he will speak the truth at all."); see also WeINSTEIN, supra note 24, I 609[02]; 2 WrGMore, supra note 2, $\$ 519$ ( $3 \mathrm{~d}$ ed. 1940) (suggesting that disqualification was part of the punishment for the crime). 
your criminal history because people like you who have been convicted of serious crimes are (now as of yore) more likely than the rest of mankind to lie under oath about whatever you are asked.

As the descendant of absolute disqualification, the modern predictor of mendacity may be one of those inherited artifacts that masquerade as the product of a contemporary and rational analysis of common experience. Legal social science-a pot of maxims, adages, and homilies about the regular behavior of average human beings-is a vital sub-dogma of jurisprudence. ${ }^{77}$ Its prized empirical tools are hunch, conjecture, and surmise; or, as its many experts prefer to put it: "common sense," "ordinary experience," and "standing to reason."

Thus, if you happen to ask a judge, or some other legal social scientist, why he or she thinks that the jury ought to hear about the defendant's record of four shoplifting convictions and one armed robbery in this trial for arson-assuming, of course, that the said defendant is so ill-advised as to choose to testify-the likely reply will be that it stands to reason that a person of that background does not deserve the same credence as one without it. ${ }^{78}$ If you press a little, you will be informed that common sense and ordinary intelligence confirm that a person who has demonstrated his contempt for social constraints will be less reluctant to lie under oath to save his hide. ${ }^{99}$ Patiently, your informant will stress that shoplifting is a crime of stealth and deception warranting the

77 See, e.g., Glick, supra note 65 , at 33I-34.

78 For example, Congressman Hogan, in debating rule 609, asserted:

Mr. Chairman, no one can object to permitting a witness to be held up to a jury as unworthy of belief because he or she had been convicted for cheating or stealing, but that surely does not exhaust the subject matter. How credible is a witness who has been convicted, let us say, for kidnapping, or for espionage, or for inciting civil disorders, or for aircraft piracy, or for assassination, or for any of a rumber of other crimes set out in title 18 of the United States Code? Does it make sense to allow a conviction for theft to be proved against a witness and not allow other felony convictions to be proved? Are we really that suspect of acts of dishonesty while willing to keep from the juries the information, for example, that a witness had been convicted for making explosive or incendiary devices with the intent to detonate them in public buildings. Personally I am more concerned about the moral worth of individuals capable of engaging in such outrageous acts as adversely reflecting on a witness' character than I am of thieves, and that comparison justifies my amendment.

120 CoNG. REc. 2376 (1974) (remarks of Representative Hogan).

79 In discussing the disqualification of felons from testifying, Bentham explained:

"In any other case, the argument for the exclusion is no more than this: He has violated the obligations of morality in some sorts of ways; therefore it is more or less probable that he will, upon occasion, violate them in this sort of way [lying]. $7 \mathrm{~J}$. Bentham, Rationale of Judicial Evmence 406 (Bowring ed. 1827), quoted in 2 WIGMore, supra note $2, \$ 519$, at 727 (Chadbourn rev. 1979). 
belief that as a witness, the perpetrator of this crime would not scruple to lie, while robbery is a serious enough offense to signify that the defendant is the sort of person who puts his own interests above those of the society. ${ }^{80}$ The same confident knowledge of human behavior demands that the credibility of a bystander describing an automobile collision be evaluated with the datum that three years before he pleaded guilty to assault with a dangerous weapon.

Despite their currency, it might be convincingly argued that these sturdy propositions do not in fact stand to reason nor accord with ordinary intelligence and common experience. Most people lie occasionally. They lie on important matters and under oath in direct proportion to their interests ${ }^{81}$ and inverse proportion to their belief that the truth can be objectively demonstrated. In this formula, the fact that a person has been convicted of a crime, any crime, deserves miniscule importance. At the same time, the evidence of prior conviction has enormous impact, tempting a factfinder to reject the felon's story without careful scrutiny. ${ }^{82}$ Furthermore, speaking only of criminal defendants as witnesses (where the crunch is), it seems quite likely that a guilty person without prior convictions will lie on the stand as readily as will a guilty veteran,

80 The New York Court of Appeals followed this reasoning in People v. Sandoval, 34 N.Y.2d 371, 377, 314 N.E.2d 413, 417-18, 357 N.Y.S.2d 849, 855 (1974):

To the extent, however, that the prior commission of a particular crime of calculated violence or of specified vicious or immoral acts significantly revealed a willingness or disposition on the part of the particular defendant voluntarily to place the advancement of his individual self-interest ahead of principle or of the interests of society, proof thereof may be relevant to suggest his readiness to do so again on the witness stand. A demonstrated determination deliberately to further self-interest at the expense of society or in derogation of the interests of others goes to the heart of honesty and integrity.

81 Arguing that a witness is qualified to testify despite past criminal offenses as Iong as evidence of these crimes is admissible for impeachment, Bentham states:

[D]ishonesty leads the witness to lie only by the medium of some interest. Even the least upright of men, when he is not under the influence of some seducing interest, and is surrounded by the restraints of the law, and exposed to the shame and punishment of false testimony, will not be so much his own enemy, as to commit a dangerous crime without any view of profit.

Examine, likewise, whether his offence has been of such a nature as to affect his credibility in the case at issue. He may formerly have given false evidence, but it was in defence of himself, or of some one who was dear to him. Does it follow, that, where he has no interest, he will commit the same crime to endanger the life of a stranger?

J. Bentraim, A Treatise on Judictar Evimence 250-51 (M. Dumont trans. 1825). 82 See, e.g., Symposium, supra note 65 , at 665 (assuming high prejudicial impact of any past crime); Note, supra note 27, at 773-74 (discussing the degree of prejudice depending on the nature of other crimes evidence). 
while innocent people with extensive criminal histories will testify as truthfully as the innocent novice. If that view is correct, the impeachment rubric is a hoax, merely a cover for the admission of evidence bearing on propensity-which is what the rule's defenders are probably seeking.

Smuggling propensity evidence into a criminal prosecution must be taken as a fairly serious offense to some cherished notions of fairness. ${ }^{83}$ However much common sense and ordinary intelligence may insist that evidence of criminal propensity is relevant, powerful considerations of policy preclude the use of prior convictions on the issue of guilt. On a theoretical level, we base our criminal justice on the precept that a person will be convicted only for what he does, not who he is or what he has done prior to the event in question. On a practical level, we will not run the risk of convicting the innocent that a propensity theorem entails. Accordingly, though the proof of prior conviction may be accepted, the jury will be repeatedly and forcefully cautioned that they are not to take the fact that the defendant has been previously convicted as any evidence whatever that he committed the crime with which he is now charged. ${ }^{84}$ If any juror paused to consider this standard instruction (and there is no report that any juror has), he or she would find it odd indeed: the jurors are told that they may not judge the defendant guilty of arson because he committed that robbery and those other larcenies, but they may consider those

83 See, e.g., Ladd, supra note 11, at 176-78 (evidence of single crime unreliable predictor of credibility or character generally); Weissenberger, Character Evidence under the Federal Rules: A Puzzle with Missing Pieces, 48 U. CIN. L. Rev. 1 (1979) (assuming propensity inferences are invalid); Note, supra note 27, at 763-64. But cf. McGowan, supra note 65 , at 8-9 \& nn.32-33 (questioning assumption that propensity inference is invalid and comparing continental experience).

84 For example, pattern jury instructions for criminal cases in the Fifth Circuit read as follows:

The fact that a witness has previously been convicted of a felony, or a crime involving dishonesty or false statement, is also a factor you may consider in weighing the credibility of that witness. The fact of such a conviction does not necessarily destroy the witness' credibility, but is one of the circumstances you may take into account in determining the weight to be given to his testimony.

As stated before, a Defendant has a right not to testify. If a Defendant does testify, however, his testimony should be weighed and considered, and his credibility determined, in the same way as that of any other witness. Evidence of a Defendant's previous conviction of a crime is to be considered by you only insofar as it may affect the credibility of the Defendant as a witness, and must never be considered as evidence of guilt of the crime for which the Defendant is on trial.

Committee on Pattern Jury Instructions, District Judges Association, Fiftix Circutr, Pattern Jury Instructions (Crmmonal Cases) 17 (1979). 
convictions in deciding whether the defendant lied when he denied committing the arson.

Apart from the illusory distinction at its core, enunciation of the rule does more to satisfy legal scholasticism than to direct the minds of real jurors. Although jurors seem to digest knotty principles, no one can believe in actual compliance with instructions of this sort. At least in a criminal case when the previously convicted witness is the defendant himself, the pretense seems cruel. Jurors cannot close one eye to the important news that the person on trial has a record of prior convictions. No one in court believes that the jury will consider this evidence only as affecting credence, particularly if the crime on trial is similar to the prior offenses. ${ }^{85}$ At the very least, the information about the defendant's background reduces the care with which the jury sifts the evidence, as they might regret a false positive less than they would with a "clean" defendant. Yet, the impossible task required of jury instructions, coupled with the grave potential of prejudice, did not escape the notice of reformers.

When the Supreme Court sent Congress a version of the rule that copied the prevailing law of the District of Columbia, the House Judiciary Committee ground it down to the hard, narrow, and clean (and radical) proposal that for ordinary witnesses and for a defendant as his own witness, impeachment could be by prior conviction only if the crime involved dishonesty or false statement. ${ }^{86}$ This idea was modified in the Senate Judiciary Committee, ${ }^{87}$ which split defendant-witnesses-who faced the greatest danger of spillover prejudice-from other witnesses, only to have the conference committee recombine the two categories. ${ }^{88}$ As passed, federal rule 609 provides that during cross-examination of any witness, it may be established that he was previously convicted of (1) a felony, if the

85 A student survey revealed that $98 \%$ of the criminal attorneys and $43 \%$ of the trial judges questioned believed that juries were unable to follow an instruction to consider prior convictions evidence for the purpose of evaluating the defendant's credibility rather than as evidence of his guilt. To Take the Stand or Not To Take the Stand: The Dilemma of the Defendant With a Criminal Record, 4 Coums. J.L. \& Soc. ProBs. 215, 218 (1968); see also Note, The Limiting InstructionIts Effectiveness and Effect, 51 MINN. L. REv. 264, $281-88$ (1966); Note, supra note 27 , at $777 \&$ n.89.

86 H.R. Rep. No. 650, 93d Cong., 2d Sess. 11, reprinted in 1974 U.S. CoDE CoNG. \& AD. NEws 7075, 7084 ("In full committee, the provision was amended to permit attack upon the credibility of a witness by prior conviction only if the prior conviction involved dishonesty or false statement.").

87 S. Rep. No. 1277, 93d Cong., 2d Sess. 14-15, reprinted in 1974 U.S. Code Cong. \& AD. News 7051, 7061.

88 H.R. REP. No. 1597, 93d Cong., 2d Sess. 9-10, reprinted in 1974 U.S. Code Cong. \& AD. News 7098, 7102-03. 
court determines that its probative value outweighs its prejudicial effect to the defendant, or (2) any crime that "involved dishonesty or false statement." 89 This evolved form unfortunately loses the welcome rationality of the House stroke, regaining only the old amalgam of dubious theory and doubtful application that preceded codification.

Take in reverse order the two uses of prior convictions allowable by rule 609 . It might at first appear that here, at least, is a moment of good thinking: a limitation of impeaching prior convictions to those involving dishonesty or false statement and therefore having a clear relation to the issue of testimonial veracity. But let us be so bold as to be naive: just what is a crime involving "dishonesty"? Because the terms are coupled in the alternative, it is evidently something other than a crime that involves "false statement." Even that latter term is not altogether self-defining. Once you pass the obvious examples in which a false declaration is an element of the crime, such as perjury, larceny by fraud, or filing false documents of various sorts, the question becomes debatable. Does the phrase contemplate crimes in which false representation is implicit or perhaps relevant to intent, such as the unlawful practice of medicine; does it refer to the instrumental use of deception in the particular instance, such as a rape committed by a man posing as a gas company inspector? Leaving astern these difficulties with the ingredient "false statement," let us explore the quality of "dishonesty" generally as a means of distinguishing one category of crime from all others for this very important purpose.

Could not an excellent case be made for the thesis that all crimes, or virtually all, involve "dishonesty"? ${ }^{90}$ The word once

89 Of the five-part rule 609 , the general proposition is put as follows:

For the purpose of attacking the credibility of a witness, evidence that he has been convicted of a crime shall be admitted if elicited from him or established by public record during cross-examination but only if the crime (1) was punishable by death or imprisonment in excess of one year under the law under which he was convicted, and the court determines that the probative value of admitting this evidence outweighs its prejudicial effect to the defendant, or (2) involved dishonesty or false statement, regardless of the punishment.

FED. R. Evm. 609(a). Paragraph (b) rules out convictions over ten years old unless the court finds them highly probative and advance notice is tendered to the adverse party. Other parts deal with juvenile adjudications, the effect of pardon, etc., and the pendency of appeal.

90 The congressional debate concerning rule 609 contains a discussion of the differences between dishonesty and false statement and whether all crimes involve dishonesty. 120 Cong. Rec. 2376-81 (1976). The speakers reach different conclusions, leaving no clear guideline. See, e.g. id. (statements of Representatives Wiggins, Danielson, and Brasco); see also Ladd, supra note 11, at 178-80 (some crimes have no probative value on the issue of the credibility of the offender). 
meant "dishonorable," and at least one current meaning of the word "honesty" is "uprightness." 91 It is often coupled (in court, at least) with the word "integrity" which, in the sense intended, means of sound and sincere moral principle. Is there any common law crime that does not, then, in some sense, "involve" conduct fairly called dishonest? As one wag put it: you have to go to law school to find out that while forgery is dishonest, burglary is not.

Separating "honest" from "dishonest" criminal conduct is a task to delight a scholastic monk. The law has long relied on verbal tags to express a supposed qualitative difference between significant moral vacuity and ordinary criminal badness. A familiar, if a bit quaint term is "moral turpidtude." 92 As Black's Law Dictionary defines that term, it appears to be a definition of crime enhanced by some rhetorical pejoratives. ${ }^{93}$ In usage, the phrase serves better as invective than as the heading for a discrete catalogue of offenses. The Senate Judiciary Committee today prefers "crimen falsi" to describe the relevant category of criminal offenses. ${ }^{94}$ Indeed, the much quoted passage in the Senate committee's report, defining this entire phrase, is a model of the lawyer's worst style of definition: rotund, synonymic, inclusive, circular, and incorporating the word being defined. It leaves the mind comforted but unnourished. Here it is (describing, remember, crimes relevant to testimonial veracity):

91 The Oxford English Dictionary (OED) includes in its definitions of honesty: "Uprightness of disposition and conduct; integrity, truthfulness, straightforwardness: the quality opposed to lying, cheating, or stealing." The OED concludes that this definition is "[t]he prevailing modern sense." V ThE OXForn ENGLISH DrctronarT 363 (rev. 1961).

92 As the Connecticut Supreme Court of Errors stated many years ago:

Logically the quality and not the penalty of the crime should fix its classification, and crimes whose commission involves an inherent baseness, and which are in conflict with those moral attributes upon which the relations of life are based, are infamous. They are said to be those which involve moral turpitude. In itself this is a vague term, lacking precision.

Drazen v. New Haven Taxicab Co., 95 Conn. 500, 506, 111 A. 861, 863 (1920).

The term still appears in the immigration context, as 8 U.S.C. $\$ 1182(a)(9)$ (1976) makes "aliens who have been convicted of a crime involving moral turpitude" ineligible to receive visas and excludable from the United States. The pages of annotations attest to the difficulty that courts experience in determining the exact meaning of moral turpitude in this context as well. See, e.g., 8 U.S.C.A. $\$ 1182(\mathrm{a})(9)$ (1970 \& Supp. 1981) (notes 139-54); see also United States ex rel. De George v. Jordan, 183 F.2d 768, 769 (7th Cir. 1950) ("We find many definitions of moral turpitude."), rev'd, 341 U.S. 223 (1951) (moral turpitude standard not unconstitutionally vague).

93 Black's Law Drctronary 910 (rev. 5th ed. 1979); see also McCormack, supra note 4 , $\$ 43$, at $85-86$ \& n.57; Ladd, supra note 11 , at 181-83.

24 See infra note 95 and accompanying text. 
By that phrase [offenses involving false statement or dishonesty], the committee means crimes such as perjury, or subornation of perjury, false statement, criminal fraud, embezzlement or false pretense, or any other offense, in the nature of crimen falsi the commission of which involves some element of untruthfulness, deceit or falsification bearing on the accused's propensity to testify truthfully..$^{95}$

By the dull gleam of this legislative prose, a diligent judge could not discern the nature of a prior misdemeanor conviction for fortune-telling, bribery, or shoplifting. Moreover, the final clause of the explanative report, describing this group of provable prior convictions as "bearing on" veracity seems to put the enumerated "crimen falsi" right back into the first part of rule 609(a), felonies relevant to propensity to lie under oath.

To recognize the true shape of the provision, then, we must examine the first category of prior crime evidence allowable for impeachment-felonies having probative value on the issue of credibility. With some limitations and exemptions that need not concern us, the federal rule provides that a defendant, or any other witness, may be confronted, by examination or by evidence, with a prior felony conviction if the judge believes that the jury will be assisted in the determination of credibility more than the defendant will be otherwise harmed by a false jury inference. ${ }^{98}$ That is as plainly as the probity-prejudice standard can be put in this context. It approximates the rules adopted and evolved in a number of jurisdictions which have tried to compromise between the appetite of the factfinder for clues to the resolution of the imponderables of credibility and the potential prejudice to the defendant of a bad criminal record. ${ }^{97}$

Right at the start, we probably should admit that the rather odd wording of rule 609 (a)(1) might simply be an indirect way of providing that, while the victim or any other witness may be impeached by any prior felony conviction, the defendant need worry

95 S. Rep. No. 1277, 93d Cong., 2d Sess. 14, reprinted in 1974 U.S. CoDE Cong. \& AD. News 7051, 7061.

96 FED. R. Evw. 609(a) (1).

97 See, e.g., United States v. Palumbo, 401 F.2d 270 (2d Cir. 1968), cert. denied, 394 U.S. 947 (1969); Gordon v. United States, 383 F.2d 936 (D.C. Cir. 1967), cert. denied, 390 U.S. 1029 (1968); Luck v. United States, 348 F.2d 763 (D.C. Cir. 1965); People v. Montgomery, 47 Ill. 2d 510, 268 N.E.2d 695 (1971). But see, e.g., Commonwealth v. West, 357 Mass. 245, 258 N.E.2d 22 (1970); State v. Hawthorne, 49 N.J. 130, 228 A.2d 682 (1967), overruled, 76 N.J. 127, I47, 386 A.2d 378, 388 (1978). 
only about those falling within the rather uncertain bounds of the "dishonesty" category: rule 609(a)(2). After all, prejudice "to the defendant" registers nil when he trots out the eyewitness's previous record for, let us say, sodomy. ${ }^{98}$ And some inferences concerning the witness's veracity can be drawn from virtually any criminal activity. ${ }^{99}$ On the other hand, the relevance to credibility is never so great that it overcomes the danger of a forbidden propensity inference when the defendant is the witness. ${ }^{100}$ If this be so, the federal rules have slipped into the law an invidious discrimination which might well affect unjustly the result in a criminal trial. ${ }^{101}$ Consider a case, not too farfetched, where both the defendant and the government's principal witness have felony records, perhaps for drug-related crimes. Both testify. The jury hears that the government witness has been previously convicted for serious crimes, but, so far as they know, the defendant has a clean past. Who would blame them for finding a reasonable doubt on that basis alone (amplified, of course, by the "skillful" summation by defense counsel)? Moreover, the rule undercuts its own rationale of relevance if it permits a defendant to testify shorn of his criminal past while a witness against him takes the stand with his credibility encumbered by his unredacted history.

98 I am less clear as to the application of the "prejudice to the defendant" test when the witness with the record is called by the defense. Does the defendant face a cognizable hazard that the jury might convict him because of his witness's unsavory background? It seems to me at least arguable that prejudice by association may protect defense witnesses from disclosure of prior convictions, particularly if the circumstances are such that the jury may find the witness and the defendant closely associated in the alleged criminal enterprise.

89 See supra notes 90-91 \& accompanying text.

100 See McConMack, supra note $4, \S 43$, at $89-90 \& \mathrm{n} .87$ (describing prejudice to the defendant when his testimony is impeached by evidence of prior convictions).

101 "Smuggled" may be an inappropriate verb to describe a deliberate choice of the legislature. It may well have been a desired consequence that the probityprejudice meter always favors the defense. Thus, for example, in United States v. Smith, 551 F.2d 348, 359 (D.C. Cir. 1976) (emphasis in original), Judge McGowan asserts that the phrase "to the defendant" in rule 609 (a)(I) "reflects a deliberate choice to regulate impeachment by prior conviction only where the defendant's interests might be damaged by admission of evidence of past crimes, and not where the prosecution might suffer, or where a non-defendant witness complains of possible loss of reputation in the community." In a footnote, Judge McGowan finds support for this conclusion in the legislative history. Id. n.21.

"Smuggle" may also be a poor choice of language for a rule so clear and apparent to observers as to be practically patent. A leading treatise, for example, states it clearly: "That is, Rule $609(\mathrm{a})(\mathrm{I})$. . . does not authorize a court to disallow defense efforts to impeach prosecution witnesses." $3 \mathrm{D}$. LouIsent \& C. MUELLER, supra note 50, \$316, at 324-25 (1979). A string of federal decisions to the same effect is supplied.

Yet it seems to me the drafter of the rule was less than forthcoming in framing a rule with such blatantly one-sided effects. If a rule admitting prior felony convictions against all witnesses except the defendant was intended, it might have been worded to state so openly. 
Beyond the jolt to sense and symmetry, consider the plight of the trial judge, enjoined to make fine distinctions, on a case-by-case basis, at least as to defendants contemplating a trip to the stand.102 How is the wisest and most meticulous judge to make an intelligent discrimination between prior convictions using a probity-prejudice test? Compared to this exercise of judicial choice, decisions on bail and sentence are models of scientific precision. Imagine the process by which a judge will determine, for example, that a defendant previously convicted of robbing a grocery store will not scruple to lie on the stand when defending against a charge of assaulting a woman in the park with a knife, compared to a man charged with the same offense who has never before been convicted? And having decided whether the prior convictions are relevant, the judge still must consider the prejudicial impact of this evidence. Can the judge rationally determine if the probative value of the robbery conviction for credibility is outweighed by the danger that the jury might believe, despite contrary instructions, that the prior conviction proves that the defendant was disposed to commit violent crimes and hence convict for the assault based in significant part on the impermissible inference of proclivity?

Undeniably, judges have been regularly making just such decisions. ${ }^{103}$ But it is quite possible that they have not been making them on the basis professed. In all but the simplest cases, it is doubtful whether those crime-weary, litigation-worn, well-meaning

102 Even though all felony convictions always may be adduced against prosecution witnesses, the rule appears to allow some prior convictions to be used to impeach the defendant as a witness. It is here, then, that the rule requires judicial deliberation. FED. R. Evm. 609(a)(1).

${ }^{103}$ According to Weinstein and Berger, courts generally conclude that crimes involving fraud may be used to impeach. Wenstern, supra note 24, $\llbracket 609[04]$, at 609-71. See United States v. Toney, 615 F.2d 277 (5th Cir. 1980) (mail fraud), cert. denied, 449 U.S. 985 (1980); United States v. Apuzzo, 555 F.2d 306 (2d Cir. 1977) (possession and transportation of untaxed cigarettes-defrauding the revenue), cert. denied, 435 U.S. 916 (1978); United States v. Brashier, 548 F.2d 1315 (9th Cir. 1976) (conspiracy to issue unauthorized securities and mail fraud), cert. denied, 429 U.S. 1111 (1977).

Crimes involving force usually are not admitted for impeachment purposes. See United States v. Lossiah, 537 F.2d 1250 (4th Cir. 1976) (disorderly conduct); Carlsen v. Javurek, 526 F.2d 202 (8th Cir. 1975) (assault and battery); Wenstern, supra note 24, $\int 609$ [04], at 609-72.

Courts differ on the admissibility of evidence of crimes involving taking of property. Compare United States v. Smith, 551 F.2d 348 (D.C. Cir. 1976) and United States v. Hayes, 553 F.2d 824 (2d Cir.), cert. denied, 434 U.S. 867 (1977) (robbery is not dishonesty with United States v. Wilson, 536 F.2d 883 (9th Cir.), cert. denied, 429 U.S. 982 (1976); United States v. Bianco, 419 F. Supp. 507 (E.D. Pa. 1976), aff'd mem., 547 F.2d 1164 (3d Cir. 1977) (robbery involves dishonesty) and United States v. Carden, 529 F.2d 443 (5th Cir.) (petit larceny involves dishonesty), cert. denied, 429 U.S. 848 (1976).

Courts also vary in their determination of the admissibility of narcotics convictions. See WeInsteIN, supra note 24, 『609[04]. 
people believe the illusion they appear to promote: that the convictions allowed to impeach a defendant-witness have greater bearing on credibility than on propensity to commit the crime charged. What actually may be going on in courtrooms where judges regularly make these determinations is this: the judge is deciding the appropriate tax to levy on the history-laden defendant's choice to testify. In the interests of fairness (and incidentally the constitutional policy not to burden unduly the exercise of the right to give evidence), ${ }^{104}$ the defendant will be relieved of some of the poison of his past. But perhaps not all of it. The judge may feel that a proven criminal should not be allowed to swear to what he will in the white cloak of a blameless citizen; that would be abusing the privilege. And so the judge, by silent processes that are undoubtedly unclear to himself, picks from among the convictions those that are serious enough to be "relevant," without being so serious or so similar to the case on trial as to be "prejudicial," and then simply concludes that the jury "ought" to hear of them if the defendant elects to testify.

Direct or perverse, the selective use of prior convictions to impeach credibility amounts to the proof of past instances of misconduct from which to infer (testimonial) behavior consistent therewith-i.e., dishonesty. There is no blinking the anomaly: rule 609 allows what rule 608 prohibits. ${ }^{105}$ The fact that the prior misdeed is evinced by a recorded conviction may facilitate and strengthen the proof of it; it cannot improve its relevance. And admitting these propensity-indicative prior misdeeds in the form of prior convictions may compound the prejudice. The convictions stamp the deed with official status, carrying both the mark of proven fact and the suggestion of continuing dangerousness. Nor is this heightened onus balanced by enhanced probity, for the bare fact of conviction of a named offense does not inform the jury of the surrounding or constituent acts and circumstances from which some notions of relevant character might be discerned. ${ }^{106}$

There are, moreover, a number of pressing matters large and small which these provisions of the federal rules leave unattended.

104 See FED. R. Evm. 608(b) advisory committee note.

105 Rule 608(b) does not conceal the conflict. It provides that: "Specific instances of the conduct of a witness, for the purpose of attacking or supporting his credibility, other than conviction of crime as provided in rule 609, may not be proved by extrinsic evidence." FED. R. Evm. 608(b) (emphasis added). The advisory committee laconically comments that the clause simply "recognized" the exception to the general rule for the case of prior conviction. Id. advisory committee note.

106 See supra text accompanying notes 70-71. 
For example, while pardoned offenses in specified instances are unavailable for impeachment, and the pendency of an appeal is admissible but otherwise insignificant, the rules give no further hint concerning the admissibility of reversed convictions, most of which may have been upset for reasons other than the innocence of the defendant. ${ }^{107}$ Too, the rule offers no suggestion concerning the admissibility of facts underlying the fact of conviction, either to enhance the probative value on credibility or, from the person impeached, to reduce it. While the advisory committee note to the preceding rule, 608 , indicates an intention to reject a famous thirtyyear-old case in New York, People v. Sorge, ${ }^{108}$ the note does not appear to disapprove of allowing examination beyond the bare fact of prior conviction for a named offense ${ }^{109}$-the proposition for which this New York decision is most often cited.

But larger, perhaps, than these gaps in the rule is its failure to afford clear guidance in the solution of the big question in the area of selective admission of prior convictions for the impeachment of a testifying defendant: should the court allow for impeachment a recent conviction for a serious offense "involving" conduct probative of credibility (according to the judge's best belief), but notably similar to the primary conduct in issue? Concretely, when a defendant testifies in defense of a charge of embezzlement of negotiable securities in Arizona, may the government impeach by a

107 One commentator notes: "Of course nothing in Rule 609(e) authorizes the use for impeachment purposes of a conviction which has already been reversed or otherwise set aside, even though such a conviction might be admissible for other purposes." 3 D. Loursell \& C. Muelder, supra note $50, \S 323$, at 376 . But it might as easily be said that nothing in the rule prohibits the use of the prior conviction merely because it was subsequently reversed or otherwise set aside.

108301 N.Y. 198, 93 N.E.2d 637 (1950).

${ }^{109}$ Sorge is cited for a variety of related propositions. At its broadest, Sorge supports judicial discretion as to the scope and range of cross-examination. People v. Duncan, 46 N.Y.2d 74, 385 N.E.2d 572, 412 N.Y.S.2d 833 (1978), cert. denied, 442 U.S. 910 (1979); People v. Duffy, 36 N.Y.2d 258, 326 N.E.2d 804, 367 N.Y.S.2d 236 (1975). Courts also cite Sorge as authority for the proposition that the questioner is not bound by the initial answer and may continue the line of questioning in an attempt to bring out a different answer. People v. Wise, 46 N.Y.2d 321, 385 N.E.2d 1262, 413 N.Y.S.2d 334 (1978). Additionally, Sorge has been cited to support the proposition that inquiry is permitted into all immoral, criminal, or vicious acts. People v. Carmack, 44 N.Y.2d 706, 376 N.E.2d 919, 405 N.Y.S.2d 446 (1978) (Cooke, J., dissenting); People v. Piranian, 77 Misc. 2d 441,354 N.Y.S.2d 72 (1974); People v. Sandoval, 34 N.Y.2d 371,314 N.E.2d 413 , 357 N.Y.S.2d 849 (1974) (restricting Sorge in this respect). In commenting on rule $608(\mathrm{~b})$, the advisory committee rejected the doctrine of Sorge and condemned the last of these uses as a violation of the constitutional protection against self-incrimination. FED. R. Evm. 608(b) advisory committee note. Most commonly, however, Sorge is cited for the proposition that the impeaching questioner is not restricted to the fact of conviction and the name of the crime for which the witness was convicted, but may probe somewhat further into illuminating aspects of the offense. 
prior conviction for a similar crime five years before in Maryland? Here, where judges grope and practice sways, the support of a rule if not a rationale would be most welcome. If the rule 609 theorem was any warrant, one might expect an answer, at least by implication, to this troublesome problem.

\section{The "Special Purpose" Exception ("KIPPOMIA")}

Of the several exceptions to the rule against the proof of characteristic prior conduct to establish the occurrence of the primary conduct in issue, the most curious is the one to which we now turn. It is an exception without a respectable name, a mongrel of diverse strains joined, it seems, by no more serious principle than happenstance. Indeed, its enumerated special purposes appear so arbitrarily collected in the rule that it is one of the few doctrines for which generations of law students have had to invent an mnemonic device to recall its elusive parts to mind. Let us look at it in the form given it by the Federal Rules of Evidence. Evidence of "other crimes, wrongs, or acts," while inadmissible to show character in order to prove conduct consistent therewith, is nonetheless allowed by rule $404(\mathrm{~b})$ for "other purposes, such as proof of motive, opportunity, intent, preparation, plan, knowledge, identity, or absence of mistake or accident." 110 (My acronym is "KIPPOMIA.")

Need we pause to puzzle over the meaning of these eight or nine items on this particular list? Should we furrow our brow over the difference between plan and preparation or between knowledge and the absence of mistake or accident? Must we scratch for examples of "other crimes, wrongs, or acts" that might prove an opportunity to perform the act in issue? Fortunately, we probably can omit this exercise. We need not here explore the application of each of these exceptional purposes, nor attempt to refine their definitions. The entire list, obviously, arrived-complete-down the chute of history. A virtually identical version can be found in a famous decision of the New York Court of Appeals written in the second year of this century, ${ }^{111}$ and several earlier treatises recite a comparable catalogue. ${ }^{112}$ The origins are doubtless obscure in the mists antedating the great treatises.

110 FED. R. Evm. 404(b). See generally Kuhns, supra note 13.

111 People v. Molineux, 168 N.Y. 264, 293, 61 N.E. 286, 294 (1901) (motive, intent, absence of mistake or accident, a common scheme or plan embracing the cornmission of two or more crimes so related to each other that proof of one tends to establish the others, the identity of the person charged with the commission of the crime on trial).

112 The Molineux court cited as authorities for the exceptions F. WHARton, Cromanal Evmence $\$ 48$ (9th ed. 1885); H. Underimi, a TrEatise on the Law 
It is enough to note that, whatever each of the KIPPOMIA items means singly, and whatever the seductive "such as" preceding the list may add to it, the aggregate describes a remarkably broad compass. Taken as a whole, the rule permits proof of prior misdeeds to show the identity of the actor, his critical state of mind, and many of the preceding and attendant circumstances of the act in issue. In criminal prosecutions at least (where the rule is most often applied), these three aspects are the common and central components of the ordinary case.

This is not to say, however, that virtually all evidence of prior misconduct is readily admissible. The proffered proof not only must be tagged with one of the enumerated KIPPOMIA purposes, it must be relevant to that issue in the evidentiary sense. The test of ordinary relevance is often an insuperable barrier. Thus, even if it could be argued that a defendant's rape of a woman in 1974 was offered to show that the defendant intended to commit the crime of rape when he allegedly broke into another woman's apartment in 1981, the inferential link is so weak (particularly when weighed against prejudice) that the proof would be excluded on basic relevance grounds. Moreover, only if the proof of the earlier event was strong and the methods employed in both incidents were unusual and very similar would evidence of the prior conduct be considered relevant to establish the identity of the perpetrator of the crime on trial. Ordinary considerations of relevance demand no less. So, despite the breadth of the KIPPOMIA opening in the barrier against the use of evidence of prior "bad acts," few such incidents in a criminal defendant's history actually have a clear enough relationship to one of the KIPPOMIA facts to get through.

Obviously, these stringencies of relevance are appropriate. Evidence of unrelated behavior-particularly antisocial behaviorshould not be allowed to clutter the trial; it should be excluded unless a strong pull of inference leads directly to some material

of Crimdnar Evmence $\$ 58$ (5th ed. Herrick 1956); A. ABbot, A Brief For the Trial of Criminal CaSes $\$ 598$ (3d ed. Barbour 1925). Molineux, 168 N.Y. at 293-94, 61 N.E. at 294. Additionally, Wigmore presents a list of cases, beginning in 1804 in England and 1829 in the United States, in which evidence of prior crimes was admitted for purposes other than to show character. I WIGMORE, supra note 2 , at 216 ( $3 \mathrm{~d}$ ed. 1940); see also 1 GREENLEAF, supra note $8, \$ 14 \mathrm{~g}$ (knowledge, intent, plan or design).

For a complete discussion of the development of the American rule and its English antecedents, see Stone, The Rule of Exclusion of Similar Fact Evidence: America, 51 HARv. L. REv. 988 (1938) (arguing the original American and English rules were inclusionary; that is, they permitted all evidence of past crimes unless used solely to show propensity and that only by misunderstanding and perversion has America developed the exclusionary rule which admits prior crime evidence only if it goes to prove motive, intent, etc.). 
trial issue. But if the strict demand of relevance is satisfied-if the inferential flow is strong and clear, surviving the twin hazards of prejudice and confusion of issue-should admissibility turn on whether the material issue to which the evidence of prior misconduct relates fits within the stated categories of KIPPOMIA? Does it make sense, for example, to admit evidence of a previous knife fight to show the defendant's motive to commit the assault in issue (a relevant but not elemental fact), but not the commission of the assault?

Consider another example. Suppose a certain jewelry merchant had on a prior occasion purchased stolen diamonds at a fraction of their value. He is now on trial for the offense of buying and receiving stolen gems. His prior experience would probably be admitted to show that on the second occasion he knew the stones were stolen at the time he bought them, but not to show that he bought them. To the ordinary human mind, struggling through life without the benefit of a legal education, the charged act-knowing acquisition of the jewels-is a single indivisible piece of behavior; the division between the prescribed and the proscribed uses of the fact of prior conviction may be a bit difficult to perceive.

The layman's difficulty, moreover, rests on a solid logical basis. The evidence of prior crime is admissible to show knowledge or the absence of mistake because a person who has once engaged in such a transaction demonstrates or acquires a trait of character that might be termed "criminal sophistication." Evidence of that trait supports the supposition that the defendant was criminally sophisticated in the transaction in question. Put more generally, evidence of the prior crime tends to prove that a defendant's conduct was criminal in the case in issue because of the assumed continuity and dominance of a relevant trait of character. Precisely the same principle would admit the evidence to prove the defendant's commission of the later crime as action in conformity with established character-the very device explicitly barred by the federal rules. It thus appears that, although an element of a crime or aspect may be proved by evidence of prior misconduct, the crime itself may not be. An inexplicable paradox can no longer be denied. If possible, it should be slain while the codifiers' iron is still hot.113

113 Those cynics, poets, or worse who do not loathe a true paradox have no business reading publications such as this one. You do not have to understand the Principia to appreciate why Russell, Whitehead, et al. spent a lifetime doing battle with the inexplicable within an otherwise ordered and rational system. See generally D. HOFSTADTER, GöDEL, EsGhER, BACH (1980). 


\section{A Synthesis and Proposal}

What this all means is that meaning is missing. The conclusion is inescapable: the foliage has grown off the trellis. Principles are twisted by exceptions, rules divide and subdivide until the offshoots lose all familial resemblance. Moreover, the hodgepodge cannot be passed off as a quaint residuum of a charming common law confusion. On the criminal side, at least, the effect of one aspect of the rule is serious injustice. In the basic business of separating the guilty from the innocent-once thought to be the main job of the criminal process-more substantive harm may result from the rule on impeachment by prior conviction, with all its supposed reforms and refinements, than from any other single feature of the system, including delay, plea bargaining, bail, sentencing disparity, and the exclusionary rule. And, on both the civil and criminal sides, charades of testimony tailored to comply with artificial exceptions are regularly accepted while useful, meaningful, and predictive evidence of character is banished. Meanwhile, earnest lawyers are forced to resort to scholasticism and stratagem to convert character to habit or propensity to motive and opportunity. The American rules of character evidence today do little credit to a profession priding itself on realistic and sensible standards to encourage the production of justice from the process of litigation.

By way of review, let us assemble the federal rules as though they had been published by the American Law Institute as a Restatement. For added interest, let us look at them upside down, as though the "exceptions" were the rule, and vice versa; thus, the major clause will be put in the affirmative. In the best I can make of it, the combined rules might look something like this:

I. A witness MAY testify:

A. To community REPUTATION or personal OPINION regarding character, where:

404(a)(1) 1. a pertinent trait of the accused is offered by him, or by the prosecutor to rebut the same;

404(a)(2) 2. a pertinent trait of a crime victim is offered by the accused, or by the prosecution to rebut the same, except in rape cases;

404(a)(2) 3. the trait of "peacefulness" of the victim is offered by the prosecution in a homicide case to rebut evidence that the victim was the first aggressor; 
608(a) 4. the trait of veracity of a witness is attacked or supported (affirmative evidence only to rebut).

B. To specific ACTS as evidence of character:

404(b)

1. for "KIPPOMIA";

405 (a)

2. on cross-examination generally;

$608(\mathrm{~b})$

3. on cross-examination specifically concerning the trait of veracity of a witness or of another person as to whose character the witness has testified;

$405(b)$

4. where the trait in question is an "essential element" of the charge, claim, or defense;

5. consisting of prior sexual behavior of a rape victim either:

412(b)(2)(A) (a) with persons other than the defendant to show defendant was not the source of semen or injury, or

$412(\mathrm{~b})(2)(\mathrm{B}) \quad$ (b) with the defendant to show consent;

609(a) 6. if the act was a crime for which the victim was convicted and

(a) it was a felony and probity outweighs prejudice, or

(b) it was an offense of any grade involving dishonesty or false statement.

406 C. To HABIT of a person or ROUTINE practice of an organization to prove conduct in accordance therewith on a particular occasion.

II. A witness MAY NOT testify, except as above:

404(a)-(b) A. Concerning any person's character, character trait, or other crimes, wrongs, or acts, in order to prove that he acted in conformity therewith on any particular occasion;

412(a)-(b) B. Nor may any person give reputation, opinion, or other evidence of the past sexual behavior of a rape victim.

At this point, finding no better way to proceed, I should like to extract from these ungainly rules their essence-both the best 
and the worst of their complex nature. I begin with the chaff. And here, I shall confine myself to the major flaws in the rules, ignoring the small oddities and petty anachronisms.

(1) The conventional parade of "character witnesses" sanctioned by the rule, offering either vague and unsubstantiated reports on general repute or personal endorsements (usually born of friendship or obligation), adds little, if anything, of relevance to the issues, and provides only a better chance of victory (or escape) to the "well-connected" party.

(2) The introduction of a prior conviction is highly damaging to a criminal defendant on the stand or to any other testifying witness. With certain special and narrow exceptions, the supposed bearing of past criminal judgment upon present veracity is tenuous at best. Moreover, the pretense of sorting the admissible prior convictions from the inadmissible is a sham, obedient to no sound principle of logic or experience, and carries serious, perhaps dispositive, consequences for the exercise of the criminal defendant's constitutional right to give evidence in his own behalf. The theory of "limited use" under which such explosive evidence is put before the jury fails to correspond to the actual effect of the evidence even in the minds of the most sober and conscientious jurors.

(3) The notion that enumerated special purposes provide open avenues to receive predictive evidence without transgressing the general ban on evidence of predisposition is foolish. Moreover, the customary list of such purposes is internally irrational and reveals no principled basis to exclude alternative allowances.

The valuable core of these rules can also be expressed in three propositions:

(1) Natural as the inference might seem to a lay observer or juror, it would be wrong to find a fact relating to material primary conduct (and particularly wrong to convict a person of a crime) because of bad or similar conduct on other occasions.

(2) When narrowly specific and nearly identical to a fact in issue, however, prior conduct may be a reliable index to characteristic behavior patterns that are likely to be repeated in similar cricumstances. In 
these cases, the predictive value of the character evidence outweighs the possibility of prejudice by improper association.

(3) Difficult as it is under the most informed circumstances, judging the witness's credibility deserves some information about highly pertinent background. or history.

From these assorted conclusions, building-even in the imagination-a sensible and useful rule to govern the admission of predictive evidence is no small undertaking. A major step is to reconstruct the foundation premise. Predisposition, so long a pariah in the law of evidence, must be reclaimed from the shadows. Its inference has been persistent and ineradicable because our common experience informs us that evidence of predisposition is probative. But our Victorian sensibilities have demanded denial, and so the influence of the banished force has been devious and distorted. If we hope to achieve rules that make sense, and if we hope to write rules to enhance the accuracy of the fact-finding process, we should abandon our frayed pretense concerning the value of character evidence. A trait of character is, almost by definition, a predisposition to characteristic conduct under appropriate circumstances. By open recognition in the law of this fact of life, we should be able to place at the center of our structure the premise that evidence of character, when relevant and more probative than prejudicial, is admissible to prove conduct consistent with, or impelled by it. If the evidence is such that the jury may infer a disposition to perform the conduct in issue, we should permit rather than prohibit them from doing so.

Having installed common truth in place of strained artificiality as the foundation stone of our reconstruction, we may commence work on the hard part of the design-an aspect that has received too little attention before now. Until we allow that inclination may affect the likelihood of occurrence, we do not reach the questions what is inclination and how is it to be demonstrated. Yet this is precisely where our attention should be directed, for this is the core of the proper concern with the use of predictive evidence: What provable fact-and specifically, what evidence of prior conduct-actually establishes that "predisposition" which will significantly raise the probability that the behavior in issue occurred? Not every event in a person's history bespeaks a trait of character, nor does character always direct the repetition of behavioral pat- 
terns. We are not such neat packages of neurological potential. Many items of conduct are wholly incidental to personality, and loosely defined character may offer no meaningful basis for predicting action. But if the observed prior conduct is of such a nature as to indicate that the act is dictated by personality-rooted in disposition to perform such acts under similar conditions-similar conduct is more likely to occur by reason thereof.

Identifying an individual as a person disposed by character to repeat certain conduct requires a good deal more than a single observed action. In deciding whether $P$ crossed against the light on April 25, for example, it is not much help to know that he had crossed against the light last February 25, even if it happened at the very same corner. Here, the act in question is too commonplace, and the example is too isolated to be of predictive value. Put another way, the isolated or common item of behavior does not constitute the evidence of individual character that might be relevant. But if $D$ 's carpool-mate can testify that $D$ rarely pauses at a particular stop sign, the evidence is probative on the question whether $D$ stopped at that particular sign on the occasion in issue. Similarly, the fact that the defendant had previously purchased some sporting goods with a credit card he knew had been stolen is relevant to the issue whether, on a later date, he forged a signature on a check to pay for some additional athletic equipment.

The point is that, either by regular repetition of a common act or by the performance of an unusual one, a person evinces a characteristic manner of behaving or reacting in given circumstances. In the ordinary course, we are justified by our common experience in believing that people continue to act in characteristic ways and hence, in similar circumstances, it becomes more likely that the predisposed defendant performed a similar act, i.e., the act in issue. Once we can demonstrate a character trait of predictive value, the resulting predisposition becomes highly probative.

I realize that as the special conditions of predictive value coalesce, the potential for prejudice also rises. It is certainly easier for the jury to disregard exculpatory defense evidence when trying a man for strangling his girlfriend with a nylon stocking, for example, after hearing evidence that he had attempted to strangle his wife in the same manner a few years before. So too, a jury will readily find that $D$ shipped defective widgets to $P$ in March after learning that he had shipped widgets with the same defect to $A, B$, and $C$ in January and February. But, if we are confident in our assessment of the predictive worth of such evidence, we need not 
fear that the obviously damaging nature of the proof will so overflow its true probative value that it might be. fairly called "prejudicial."

Moreover, while calling proof of disposition by its right (and forbidden) name, and admittedly discarding the KIPPOMIA list, I have circumscribed tolerance with some conditions that substantially reduce the hazard of prejudicial effects. I. would require three threshold criteria for the admission of evidence of. character from proof of prior conduct to show action consistent therewith: (1) the previous conduct and the circumstances of its performance must be highly specific; (2) such conduct must be clearly comparable to the behavior and circumstances in issue; and (3) only repeated or unusual instances of conduct may be treated as behavior-regulating, and hence characteristic and relevant. These are rather rigorous tests for a piece of proffered proof to pass. I deem all three necessary to enhance probative value, at the same time diminishing risk of prejudice.

I also believe that, when it comes to something as fluid and as readily subject to misinterpretation as character, special care must be taken to filter out the weak and mistaken assessments. Of the three sources of character evidence-community repute, individual opinion, and significant behavior-the most dangerous is the most commonly admitted under prevailing norms: reputation. First, of course, the convention for eliciting such evidence is often a hollow form. A witness rarely reports on the general community regard, as the form requires, but merely projects his personal opinion into the hypothetical minds and conversations of an ill-defined group of anonymous neighbors and associates. ${ }^{114}$ But even if the character witness in this mode of proof were actually reporting on the com: munity view of the party's character for, let us say, pacific deportment, what do we know about the behavior taken into account, the thought processes of the assorted people, or the clarity of communication employed to arrive at this consensus? Obviously, very little. At best, the witness cannot know or say what errors, malice, or invention fed the local rumor market. In the interests of simple probity, then, I would not allow such reports of supposed community intelligence for any trait of character.

114 Everyone who took Evidence in law school remembers the amusing account of President Theodore Roosevelt on the stand as a character witness as lawyers vainly tried to keep his hearty endorsement within the forms of the reputation rule. For the few unacquainted with the story, it may be found in D. Lourser., J. Kaplan \& J. Waltz, Cases and Materials on Evidence 387-91 (3d ed. 1976). 
Evidence of character in the form of a witness's personal opinion, now tolerated by the federal rules, is surely superior to evidence of general repute. At least the source of the characterization is on the stand subject to examination concerning the nature of the supporting data and the quality of the judgment process. Bias could be exposed and casual conclusions revealed; the factfinder might like to have a basis for assessing whether the proffered evidence actually does establish character and justify the conclusion of predisposition. So evidence in this form should be received. Even so, caution is called for lest the character witness serve no more enlightening function than a backslap. The hearty endorsement of a prominent (or at least respectable) compurgator may be a good way to pay off old debts, but it has about as much probative value as a pin-striped suit. Therefore, evidence of character in the form of personal opinion should come in only when tightly bound to a particular and narrowly described trait in issue, and when subject to cross-examination on the predicate facts.

Finally, consider the source of character evidence traditionally viewed with greatest suspicion: specific instances of prior conduct. As already indicated, here the test should be whether the prior conduct, by its unusual nature or its regular occurrence, can be fairly said to demonstrate a characterological predisposition to behave in a similar fashion under similar circumstances. But what if the previous conduct was the basis for a criminal conviction-is it then necessarily conduct of such importance that it indicates character and the likelihood of repetition? Are impulses strong enough to break social taboo also strong enough to emerge again in behavior on subsequent occasions? Perhaps, but if so the relevance and probative weight lies in the conduct, not in the fact of criminal conviction on account thereof. Except in the rarest case, the fact of criminal conviction adds no information of relevance to a witness's credibility or to any other fact in issue. Apart from the occasional efficiency of proof by a single legible piece of selfauthenticating paper, the fact that a particular item of relevant prior conduct resulted in a conviction must be regarded as evidentiary surplusage. It should not be permitted to aggravate the relevant underlying conduct by burnishing it with official condemnation. Moreover, another person in another case who did the same act without either the bad luck to be caught or the misfortune of conviction should stand in no better position as a witness or party.

Thus, the fact that a criminal prosecution followed the relevant conduct seems to me wholly irrelevant and $I$ would not allow 
proof of the fact of conviction. Of course, proof of the underlying criminal conduct would not be barred because of the prosecution that followed it, regardless of its outcome. I would, however, allow. the person against whom the underlying conduct is charged to adduce, at his option, the fact that he had been acquitted in the criminal prosecution based upon the asserted misconduct. Although not dispositive, surely that fact tends to confirm the defendant's denial of the conduct attributed to him.

The evidence of prior conviction, neatly packaged for proof, might also be used to rebut a denial of the underlying act by the witness from the stand. When inquiry is permitted, under the proposed reconstruction, the misconduct must be either clearly relevant to some item of primary behavior in issue, or directly probative of credibility. In the first instance, the matter is, by definition, noncollateral and the general rule allows rebuttal of a denial by extrinsic evidence. Proof of conviction for the conduct in question is one form of such extrinsic contradiction. And the witness-defendant or other witness can hardly complain of the prejudicial form of the evidence that demonstrates the falsity of his testimonial denial. If the claim is that the denial is true and the conviction erroneous, the witness can, of course, so testify from the stand. In the second instance, when evidence of prior misconduct is offered to attack what I have termed "secondary" be: havior (i.e., testimonial veracity), the question is more difficult. Matter inadmissible on any issue save credibility is usually deemed collateral and extrinsic evidence in contravention normally precluded. I have tried, however, to limit inquiry into prior misconduct for purposes of attacking veracity to those situations clearly. corresponding to the testimonial circumstances. When relevant prior misconduct is limited to fraud or deception under a duty of truthtelling, the collaterability rule should probably bend to allow rebuttal of a denial by extrinsic proof of a criminal conviction on account thereof. Again, of course, the witness should be asked about it in order to have the opportunity to explain or deny the contradiction.

In sum, evidence of prior conviction should not be adduced against any non-testifying person, and for those who do become witnesses, such fact might be used only to rebut a denial of the underlying misconduct and extrinsically introduced only upon the witness's denial of his conviction after an opportunity to explain it. Live, first-hand evidence of the prior conduct is obviously more useful than the recorded fact of conviction for it. The reporting 
witness is available for examination and for challenge on the surrounding context, which is vitally important to both admissibility and to probative weight under this proposed scheme. Circumstances, not consequences, may enlighten a trial issue.

To this general rule, one exception might be allowed, for in this instance only, the fact of prior criminal conviction might be of some probative force in itself. It is surely relevant to impeach the credibility of a testifying witness who, on a previous occasion, had not only lied under oath, but did so in an identical setting: from the witness stand at a criminal trial. The fact that the witness on both occasions was the defendant obviously adds to the prejudice side of the balance, but materiality is so high that it is difficult to discard the evidence. Proof that the witness lied as a witness for himself as a defendant on a prior occasion would be had by the proponent's submission that (1) the witness had so testified, (2) the substance of his testimony was necessarily inconsistent with his guilt, and (3) he was convicted. Supporting authority is embarrassingly scarce for what appears so logical an application of the rule of relevance, ${ }^{115}$ but absent a principled basis to discard the rule, I incorporate it into my proposed scheme.

In addition, there may be occasions when someone's primary conduct in issue involves truthtelling under duty or oath, although the actor does not testify. Relevance is almost as high in this case, and again it seems to me there is no good reason to exclude the prior event at which a jury of twelve implicitly but necessarily rejected the person's account under oath. Here again, the usual mode of proof-extrinsic-should obtain, with the burden of demonstrating pertinence falling upon the tendering party. Because the

115 See United States v. Hayes, 553 F.2d 824, 828 (2d Cir.) (quoting Gordon v. United States, 383 F.2d 936 (D.C. Cir. 1967), cert. denied, 390 U.S. 1029 (1968)), cert. denied, 434 U.S. 867 (1977). In permitting introduction of prior crimes, the court used as a factor in determining the balance between prejudice and probative value the fact that the defendant had testified at the trial that resulted in his conviction.

In Gordon, Judge (now Chief Justice) Burger wrote:

The relevance of prior convictions to credibility may well be different as between a case where the conviction of the accused was by admission of guilt by a plea and on the other hand a case where the accused affirmatively contested the charge and testified, for example, that he was not present and did not commit the acts charged. In the latter situation the accused affirmatively puts his own veracity in issue when he testifies so that the jury's verdict amounted to rejection of his testimony; the verdict is in a sense a de facto finding that the accused did not tell the truth when sworn to do so. Exploration of this area risks a diversion which may well be time consuming; hence use of this inquiry should be limited.

383 F.2d at 940 n.8. 
relevant fact is the asserted inconsistency between prior testimony and prior verdict, it may be possible to adduce the fact without reference to the crime for which the present witness was previously convicted. On a sufficient foundation, laid out of the jury's presence, the court might judicially notice necessary facts without allowing extraneous and prejudicial material to come in with it. Or counsel might work out a satisfactory stipulation. It is probably a rare case; discretion may be called for.

Perhaps it would be useful at this point to sketch my proposal in the form of a statutory model. I submit it only by way of legal shorthand, knowing that the breeze of challenge and justification is required to make any of its components fly.

\section{As to Primary Conduct}

When otherwise competent and relevant, and in accordance with the following rules, evidence of character shall be admissible against any party or other person whose prior conduct is a material issue.

A. Such evidence of character may be given by extrinsic evidence concerning:

(1) opinion, but only as to the trait of rectitude or other traits narrowly defined and modified by circumstances closely resembling the situation in issue;

(2) specific instances of prior conduct, but only by repeated, habitual, or unusual incidents of similar behavior in similar circumstances. Provided, however, that if the person in question testifies before such evidence is offered, the party intending to introduce it must first question the witness concerning the prior incidents. If the prior conduct is admitted in all pertinent particulars, extrinsic evidence of the same shall be excluded as cumulative.

B. The fact that otherwise relevant prior conduct formed the basis for a criminal prosecution is immaterial,

(1) and the fact that the defendant in the prior prosecution was convicted shall not be admitted in evidence,

(2) but the fact that the prior prosecution resulted in acquittal, or that a conviction thereon was reversed for insufficient evidence, shall be admitted at the instance of the person whose character is being attacked; 
(3) if the material conduct in issue involves the duty of a person to render a truthful account, and if such person testified previously as a defendant in a manner necessarily inconsistent with guilt and was thereupon convicted, the court in its discretion may allow such facts in evidence in a manner designed to minimize possible prejudice.

\section{As to Secondary Conduct}

Evidence of character shall be admissible on the issue of veracity of any testifying witness in accordance with the following rules. Such evidence may be obtained by:

A. Examination or cross-examination concerning:

(1) specific instances or prior conduct involving truthtelling under oath or duty, or

(2) prior criminal conviction after trial at which the witness testified as a defendant in his or her behalf in a manner inconsistent with the verdict.

B. Extrinsic evidence, by opinion, or specific instances of behavior concerning only the trait of truthtelling under duty.

\section{Conclusion}

In sum, character evidence cannot and should not be banished from the field of proof. Humans have always sought to read one another's character and often base important decisions on these judgments. Inescapably, character does tend to prove a fact to which it may be relevant by establishing a proclivity or tendency to do the act in question or to perform with a critical intelligence or understanding. Yet today, character evidence most often appears either in burlesque of its function, or as a product of an arcane legalistic wordplay, or as a cruel and senseless shard of forgotten dogma. It is foolish to exclude helpful evidence simply because it tends to prove the fact by proving predisposition to perform it. Relevant is relevant. At the same time, character as a basis for inferring conduct consistent with it is notoriously subject to the abuses of baseless gossip, errant conclusion, and downright malice, and the law of evidence too has become the captive of these wayward conjectures. Rules and restrictions have proliferated in defiance of the efforts to restore some order and reliability to the patch of the law of evidence. Stern discipline and brave departure are called for. Simple reliance on relevance principles will not 
tame these recurring problems. Yet, there is much in the common wisdom of character prediction that merits preservation and application to the difficult business of factfinding. With a bit of effort to find the sturdy precepts and to cut loose the facile accretions and the meaningless circumscriptions, $I$ believe it is possible for drafters, who are today engaged in the good work of codification for the states, to construct a good rule, despite the poor example set by the federal rules. 